\title{
Calibration of Meter Line Standards of Length at the National Bureau of Standards
}

\author{
Benjamin L. Page
}

\begin{abstract}
The results of intercomparisons of the total lengths of several meter bars and of calibrations of the subintervals of some of these bars for the past twenty years are reported. Information both on the degree of stability of these standards and on the precision with which such measurements can be repeated was obtained. The results are critically analyzed and comments made as to the precautions necessary in the precision comparisons of line standards of length.
\end{abstract}

\section{Introduction}

It is known that the length of a linear standard, at any specified temperature, cannot be assumed to remain the same over a period of years. The changes in length may be attributed to secular changes, although these changes are not necessarily uniform throughout the length of any linear standard. It is essential, therefore, that linear standards be recalibrated at sufficiently frequent intervals so that these calibrations may be relied upon to the requisite accuracy in their use.

The standard length in the United States is Prototype Meter 27, kept at the National Bureau of Standards. In addition to this meter bar, the National Bureau of Standards has other line standards of length that are used as working standards, and nine of these were included in the calibrations described in this paper. To calibrate these standards, intercomparisons by pairs are made, using different combinations in order to determine the most probable corrections to their total lengths. As these intercomparisons require measurements of the highest accuracy, only one pair of bars can be compared on any one day. A complete intercomparison, therefore, requires an observing period of months, and these complete intercomparisons are made at intervals of several years. A previous paper ${ }^{1}$ describes the determination of the total lengths of some of the present NBS standards and also the results of that and earlier intercomparisons.

Inasmuch as a complete intercomparison of 10 meter bars is a time-consuming labor, the question arises as to whether or not statistical methods would diminish this labor without significant loss of accuracy. This paper discusses this question and gives the analysis. It also reports the intercomparisons that have been made since the report in 1934 and shows the trends in the length changes of these bars. Redeterminations of the calibration corrections of some of the subintervals of the subdivided linear - standards have also been made.

\section{Description of meter bars}

Nine meter bars were intercompared in 1952 and 1953, and the results of these comparisons are dis-

${ }^{1}$ Lewis V. Judson and Benjamin L. Page, J. Research NBS 13, 757 (1934) RP743. cussed. Four of these bars are made of platinumiridium, one of 42 percent nickel-steel, three of invar, and one of stainless steel ( $\mathrm{Fe}-\mathrm{Cr}$ ).

The four platinum-iridium bars have a modified $\mathrm{X}$ cross section generally referred to as the Tresca section; the others have the more familiar $\mathrm{H}$ cross section, and all intervals are defined by lines ruled on the plane of the neutral axis. When in use, each bar is supported at the Airy points, which are located $28.55 \mathrm{~cm}$ in each direction from the center of the bar.

Prototype Meter 27 is the primary standard of length of the United States, and meter 21 is a second bar of the same series. The other two platinumiridium meters, 4 and 12, are of an earlier melt known as Alloy of 1874. The four nickel-steel bars are: Meter 39, made of invar, was obtained in 1903; meter $153 \mathrm{R}$, made of 42 percent nickel-steel, with an inlaid platinum strip on which the graduations are ruled, was obtained in 1911; meter $814 \mathrm{~B}$, made of invar, was obtained in 1931; and meter 752, made of a type of invar termed "Fix Invar", was obtained in 1938. The other bar of this group, meter 50, is made of stainless steel and was graduated by C. G. Peters, formerly of the Bureau, by use of wavelengths of light.

The four nickel-steel bars were obtained from the Société Génevoise d'Instruments de Physique of Geneva, Switzerland, and are graduated at intervals of $1 \mathrm{~mm}$ throughout their lengths. Meter 4 is similarly graduated. Meters 27 and 21 have only the $1-\mathrm{m}$ interval, which is defined as the interval from a central line of a group of three at one end to the central line of a similar group at the other end. Meter 12 was recently regraduated by C. G. Peters, while a member of the Bureau. Originally, this bar had rather inferior graduations at the terminal ends. This bar is considered as two linear standards for the purpose of these calibrations, because two 1-m intervals were graduated on it with a common zero; one interval is nominally correct at $0^{\circ} \mathrm{C}$ and the other at $20^{\circ} \mathrm{C}$.

On all the bars subdivided to millimeters there is a 1-mm interval subdivided to tenths ruled outside of the terminal graduations. These may be conveniently used for the determination of the screw values of the micrometer microscopes.

Meter 50 has only a zero line and a 1-m line. 
On each bar two parallel lines approximately 0.2 $\mathrm{mm}$ apart are ruled at right angles to the graduations. Only that portion of a graduation lying between the two parallel lines is considered when measurements are made. These longitudinal lines are also very convenient when alining the bars in the comparator.

Table 1 gives coefficients of the linear thermal expansion of the meter bars, previously determined at the Bureau International des Poids et Mesures (BIPM) and the National Bureau of Standards (NBS). This table gives the values of $a$ and $b$ of the general equation

$$
L_{t}=L_{0}\left(1+a t+b t^{2}\right),
$$

where $L_{t}$ is the length of the bar at any temperature near $20^{\circ} \mathrm{C}$, and $L_{0}$ is the length at $0^{\circ} \mathrm{C}$.

TABLE 1. Coefficients of expansion of the meter bars

\begin{tabular}{|c|c|c|c|}
\hline \multirow{2}{*}{$\begin{array}{l}\text { Meter } \\
\text { bars }{ }^{1}\end{array}$} & \multirow{2}{*}{ Alloy } & \multicolumn{2}{|c|}{ Coefficients of expansion } \\
\hline & & $a$ & $b$ \\
\hline $\begin{array}{r}4(1874) \\
12(1874) \\
21 \\
39\end{array}$ & $\begin{array}{l}\text { Platinum-iridium } \\
\text { Invar } \\
\text { do do }\end{array}$ & $\begin{array}{l}8.6210 \times 10^{-6} \\
8.6014 \\
8.6014 \\
8.6210 \\
1.54\end{array}$ & $\begin{array}{l}+0.00180 \times 10^{-6} \\
+.00180 \\
+.00180 \\
+.00180\end{array}$ \\
\hline $\begin{array}{r}153 \mathrm{R} \\
752 \\
814 \mathrm{~B} \\
50\end{array}$ & $\begin{array}{l}42 \% \text { nickel-steel } \\
\text { Fix Invar } \\
\text { Invar } \\
\text { Stainless steel }(\mathrm{Fe}-\mathrm{Cr})\end{array}$ & $\begin{array}{r}7.009 \\
0.997 \\
1.13 \\
10.25\end{array}$ & $\begin{array}{l}+.00083 \\
+.00402 \\
\end{array}$ \\
\hline
\end{tabular}

Meters 27 and 21 are of the principal national series of prototypes; meters 12 and 4 of the alloy of 1874 ; meters $39,153 \mathrm{R}, 752$, and $814 \mathrm{~B}$ have serial numbers of the Société d'Instruments Ide Physique: and meter 50 was graduated at the National Bureau of Standards. Meter $153 \mathrm{R}$ has an inlaid platinum strip on which the graduations are ruled.

\section{Description of Longitudinal Comparator}

The comparator (fig. 1) used in these calibrations is located in a constant-temperature room in the basement of the NBS South Building. It is mounted on a massive concrete pier whose upper surface is approximately $20 \mathrm{~cm}$ below the level of the floor of the room and entirely independent of it. This comparator is a longitudinal comparator; the relative motion of the microscope beam and of the bars being calibrated is in the direction longitudinal to the axis of the bars. In the NBS comparator the bars are stationary with their axes colinear, and a carriage with a beam bearing two microscopes is movable in a longitudinal direction. The microscopes may be clamped to the beam so that a simultaneous comparison of two bars may be made. Subdivisions of a bar up to $2 \mathrm{~m}$ in length (approximately $80 \mathrm{in}$.) may also be calibrated. The comparator has an over-all length of $4 \frac{1}{2} \mathrm{~m}$.

The longitudinal movement of the carriage is effected by two electric motors geared to provide linear speeds of the carriage from 0.1 to $10 \mathrm{~mm} / \mathrm{sec}$. Automatic braking is provided so that the carriage can be stopped within a few microns of any desired position. An automatic cutoff is also provided for stopping the motion of the carriage to prevent its running off the ways of the bed. The total travel of the carriage is $130 \mathrm{~cm}$.

The beam on which the microscopes are mounted is attached to the movable carriage through a system of self-alining ball bearings and a link, so that the beam will have a minimum strain resulting from any distortions of the carriage caused by longitudinal displacement of any magnitude up to $130 \mathrm{~cm}$, regardless of the distance between microscopes.

The two microscopes have tubes approximately $45 \mathrm{~mm}$ in diameter and $450 \mathrm{~mm}$ in length and have provision for adjustment. The total magnification as used in these calibrations is approximately 160 diam. The smallest division of the micrometer drums is equivalent to $0.50 \mu$, measured at the focal plane of the microscope. By use of a vernierscale adjacent to the micrometer drum, it is possible to estimate to $0.005 \mu$.

The graduations on the standards are illuminated by means of the vertical illuminators in the microscopes, using low-voltage lamps. Heat-absorbing glass installed between the lamps and microscopes greatly reduces the heat radiation from the lamps and therefore the temperature gradients within the bars being calibrated. Each microscope is mounted in a holder that can be moved along the ways of the beam, and may be securely clamped at any position. Also provided is a slow-motion mechanism for the longitudinal movement of the microscopes. The range in separation of the microscopes is from 15 to $210 \mathrm{~cm}$.

Two main supports for the bars are provided, and each is capable of complete adjustment for focusing and alining the bars, so that the parallel longi-

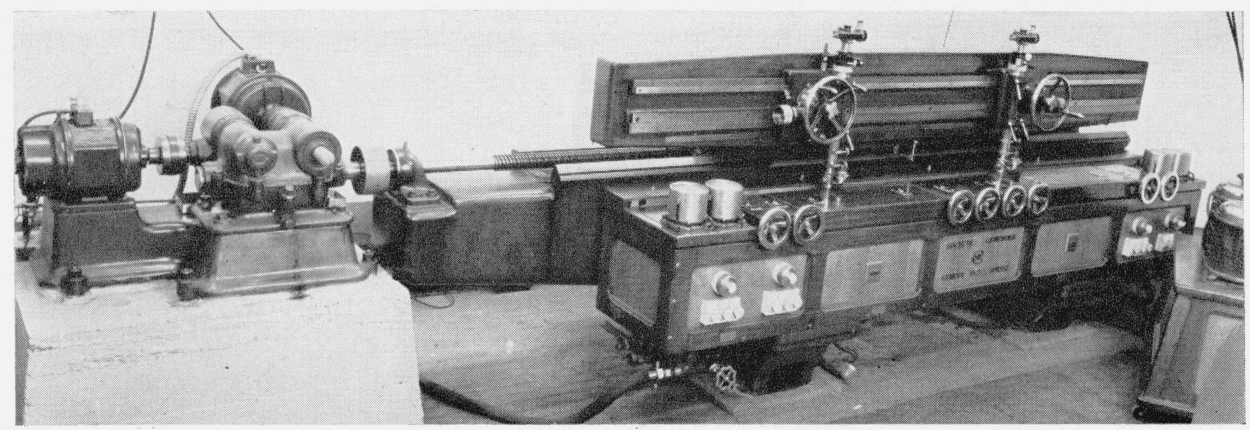

Figure 1. Longitudinal comparator of the National Bureau of Standards. 
tudinal lines on the bars are parallel to the motion of the microscopes and are centrally located in the fields of the microscopes. Two adjustable roller supports, about $1 \mathrm{~cm}$ in diameter, are clamped to each of the main supports, with the proper separation, for supporting the bars. These supports are mounted in the inner of two tanks, which may serve as a double bath, the outer one being suitably insulated. Water may be used in either or both tanks and circulated by means of motor-driven propellers. Apertures, about $25 \mathrm{~mm}$ in diameter, are provided in the cover directly above the bar graduations that are under observation.

During the measurements the entire instrument is protected against external sources of heat by a thick quilted insulating cover, so that only the micrometer boxes are exposed.

\section{Calibration of the Meter Bars}

The latest fundamental measurements on this group of nine meter bars (considered as 10 for the purpose of these calibrations) were begun in 1952 and completed in 1953. The results of previous fundamental and auxiliary measurements of the total lengths of these bars, together with some repetitions of present measurements of some of the subintervals to show the stability of various standards over a period of years and the repeatability of present comparisons, are included in this paper. Another important part of the work was the calibration of certain of the subintervals of the bars subdivided to millimeters to provide accurate secondary standards for the calibration of line standards that are shorter than $1 \mathrm{~m}$.

\subsection{Determination of Total Length}

All measurements on the bars were made on the longitudinal comparator, with the temperature of the room thermostatically controlled at $20^{\circ} \mathrm{C}$. The bars were allowed to remain in the comparator for 24 $\mathrm{hr}$, so that they would be in thermal equilibrium at a temperature very near $20^{\circ} \mathrm{C}$ before the measurements were begun. All measured differences in the lengths between any two bars were reduced to $20^{\circ} \mathrm{C}$, by using the values for their respective coefficients of linear thermal expansion shown in table 1, before computing their respective corrections. For convenience, the corrections to the standards are given instead of the actual lengths. The actual length is equal to the nominal length plus the correction; hence, a plus correction indicates that a standard is longer than the nominal length.

Prior to the comparison in 1952 and 1953, the thermal conditions of the bars in the comparator were investigated. The temperature differences between bars, as indicated either by thermocouples or by mercury thermometers, were in agreement to approximately $0.005 \mathrm{deg} \mathrm{C}$.

In order to determine the effect that water in the outer tank would have on the temperature of the bars in the inner tank, the outer tank was filled with water at nearly the same temperature as the bars. After the water had been circulated manually, there was no perceptible reduction in the temperature gradients within each bar nor was the difference in temperature less between the bars. The motors were then used to circulate the water for $2 \mathrm{~min}$. Over the period of an hour after the motors had been turned off the temperature of the air rose $0.03 \mathrm{deg} \mathrm{C}$, and the temperature of the bars remained constant. The conclusion is that the thermal conditions in this comparator are considerably less stable when the circulating bath is used, because of the heat generated by the motors.

The 10 bars selected for standardization were placed in the comparator, two at a time and in a random manner with respect to their relative positions, either to the right or to the left. To determine the magnitude of any possible bias because of the location of a standard in either the left or right end of the comparator, several auxiliary intercomparisons of groups of 5 and 6 of the bars were made. A special observing schedule suggested by the Statistical Engineering Section of the National Bureau of Standards, whereby the bars were mounted in a symmetrical manner, showed that there was possibly a small bias, which was considerably smaller than the reproducibility claimed for the measurements. All measurements were made with the bars in air at a controlled temperature of approximately $20^{\circ} \mathrm{C}$, and no water was circulated in the outer tank.

To obtain the difference in length of two bars, two microscopes separated by a distance of $1 \mathrm{~m}$ were focused on the 0 - and 1-m graduations of one of the bars. Micrometer observations were then made on this bar, the procedure being to record 2 observations on the left microscope, 4 on the right, and then 2 on the left. The carriage was then moved so that the microscopes were over the 0 - and $1-\mathrm{m}$ graduations of the other bar, and these graduations were brought into focus. Observations were then made on this bar. For convenience in computing, the bar at the right was always designated as $A$ and the other as $B$. The comparisons between each pair of bars, $A$ and $B$, were repeated 10 times, and the temperature of each bar was recorded. The procedure was to observe first on $B$, move the carriage to the right, observe on $A$, repeat the observations on $A$, return the carriage to the left, and observe on $B$. This cycle was repeated 5 times, and thus a total of 10 differences was obtained. The mean of these 10 differences was reduced to $20^{\circ} \mathrm{C}$, and the difference in the length of the bars, $L=A-B$, thus determined. This method was continued until each bar had been compared with all others, and a total of $[N(N-1)] / 2$, or 45 differences, had been determined. The results obtained are shown in table 2 .

The reduction of these observed differences by the method of least squares was carried out by the use of the form ${ }^{2}$ shown in table 3 .

The differences, $v$, between the observed and calculated differences are shown in table 3 . These

${ }^{2}$ A. Pérard and C. Volet, Les mètres prototypes du Bureau International, Travaux et Mémoires du Bureau International des Poids et Mesures 21, (1945). 
TABLE 2. Differences in length of meter bars at $20^{\circ} \mathrm{C}$

(1953 series of comparisons)

Observations made at temperature, $t$, and reduced to $20^{\circ} \mathrm{C}$, using the values of the coefficients of linear thermal expansion given in table 1.

\begin{tabular}{|c|c|c|c|c|c|}
\hline \multirow{2}{*}{\multicolumn{3}{|c|}{$\begin{array}{l}\text { Meter bars } \\
\text { compared }\end{array}$}} & \multirow{2}{*}{$\begin{array}{c}\text { Observed } \\
\text { difference, } \\
\qquad L\end{array}$} & \multicolumn{2}{|c|}{$\begin{array}{c}\text { Observed } \\
\text { temperature, } t\end{array}$} \\
\hline & & & & $A$ & $B$ \\
\hline $\begin{array}{c}A \\
4 \\
12 \mathrm{a} a \\
12 \mathrm{~b} b \\
21 \\
39 \\
153 \mathrm{R} \\
752 \\
814 \mathrm{~B} \\
50\end{array}$ & $\begin{array}{l}\text { minus } \\
\text { minus } \\
\text { minus } \\
\text { minus } \\
\text { minus } \\
\text { minus } \\
\text { minus } \\
\text { minus } \\
\text { minus }\end{array}$ & $\begin{array}{l}\text { B } \\
27 \\
27 \\
27 \\
27 \\
27 \\
27 \\
27 \\
27 \\
27\end{array}$ & $\begin{array}{r}\mu \\
-4.33 \\
+0.87 \\
-171.93 \\
+5.11 \\
-177.13 \\
-23.70 \\
-179.80 \\
-170.34 \\
-171.40\end{array}$ & $\begin{array}{c}{ }^{\circ} C \\
19.87 \\
20.13 \\
20.17 \\
19.96 \\
19.89 \\
20.01 \\
20.14 \\
19.93 \\
20.07\end{array}$ & $\begin{array}{c}{ }^{\circ} \mathrm{C} \\
19.78 \\
20.03 \\
20.05 \\
19.88 \\
19.81 \\
19.90 \\
20.04 \\
19.89 \\
20.01\end{array}$ \\
\hline $\begin{array}{c}12 \mathrm{a}^{\mathrm{a}} \\
12 \mathrm{~b}^{\mathrm{b}} \\
21 \\
39 \\
153 \mathrm{R} \\
752 \\
814 \mathrm{~B} \\
50\end{array}$ & $\begin{array}{l}\text { minus } \\
\text { minus } \\
\text { minus } \\
\text { minus } \\
\text { minus } \\
\text { minus } \\
\text { minus } \\
\text { minus }\end{array}$ & $\begin{array}{l}4 \\
4 \\
4 \\
4 \\
4 \\
4 \\
4 \\
4\end{array}$ & $\begin{array}{r}+5.36 \\
-167.68 \\
+9.36 \\
-172.88 \\
-19.50 \\
-175.53 \\
-165.99 \\
-167.19\end{array}$ & $\begin{array}{l}19.86 \\
19.88 \\
19.89 \\
20.06 \\
20.10 \\
19.97 \\
20.13 \\
19.87\end{array}$ & $\begin{array}{l}19.84 \\
19.90 \\
19.89 \\
20.04 \\
20.00 \\
19.93 \\
20.05 \\
19.86\end{array}$ \\
\hline $\begin{array}{l}12 \mathrm{~b}^{\mathrm{b}} \\
21 \\
39 \\
153 \mathrm{R} \\
752 \\
814 \mathrm{~B} \\
50\end{array}$ & $\begin{array}{l}\text { minus } \\
\text { minus } \\
\text { minus } \\
\text { minus } \\
\text { minus } \\
\text { minus } \\
\text { minus }\end{array}$ & $\begin{array}{l}12 a^{a} \\
12 a^{a} \\
12 a^{a} \\
12 a^{a} \\
12 a^{a} \\
12 a^{a} \\
12 a^{a}\end{array}$ & $\begin{array}{r}-173.01 \\
+4.33 \\
-177.99 \\
-24.68 \\
-180.65 \\
-171.40 \\
-172.56\end{array}$ & $\begin{array}{l}19.81 \\
20.10 \\
19.72 \\
20.14 \\
19.83 \\
19.89 \\
20.09\end{array}$ & $\begin{array}{l}19.81 \\
20.10 \\
19.74 \\
20.13 \\
19.84 \\
19.90 \\
20.10\end{array}$ \\
\hline $\begin{array}{c}21 \\
39 \\
153 \mathrm{R} \\
752 \\
814 \mathrm{~B} \\
50\end{array}$ & $\begin{array}{l}\text { minus } \\
\text { minus } \\
\text { minus } \\
\text { minus } \\
\text { minus } \\
\text { minus }\end{array}$ & $\begin{array}{l}12 b^{b} \\
12 b^{b} \\
12 b^{b} \\
12 b^{b} \\
12 b^{b} \\
12 b^{b}\end{array}$ & $\begin{array}{r}+177.36 \\
-5.01 \\
+148.40 \\
-7.62 \\
+1.96 \\
+0.50\end{array}$ & $\begin{array}{l}20.12 \\
19.74 \\
20.18 \\
19.81 \\
19.90 \\
20.05\end{array}$ & $\begin{array}{l}20.13 \\
19.75 \\
20.18 \\
19.79 \\
19.91 \\
20.05\end{array}$ \\
\hline $\begin{array}{c}39 \\
153 \mathrm{R} \\
752 \\
814 \mathrm{~B} \\
50\end{array}$ & $\begin{array}{l}\text { minus } \\
\text { minus } \\
\text { minus } \\
\text { minus } \\
\text { minus }\end{array}$ & $\begin{array}{l}21 \\
21 \\
21 \\
21 \\
21\end{array}$ & $\begin{array}{r}-182.36 \\
-28.80 \\
-184.94 \\
-175.46 \\
-176.45\end{array}$ & $\begin{array}{l}20.13 \\
19.90 \\
19.86 \\
19.96 \\
19.95\end{array}$ & $\begin{array}{l}20.13 \\
19.83 \\
19.84 \\
19.95 \\
19.95\end{array}$ \\
\hline $\begin{array}{l}153 \mathrm{R} \\
752 \\
814 \mathrm{~B} \\
50\end{array}$ & $\begin{array}{l}\text { minus } \\
\text { minus } \\
\text { minus } \\
\text { minus }\end{array}$ & $\begin{array}{l}39 \\
39 \\
39 \\
39\end{array}$ & $\begin{array}{r}+153.20 \\
-2.66 \\
+6.96 \\
+5.66\end{array}$ & $\begin{array}{l}19.80 \\
19.70 \\
20.06 \\
20.04\end{array}$ & $\begin{array}{l}19.85 \\
19.66 \\
19.93 \\
20.05\end{array}$ \\
\hline $\begin{array}{l}752 \\
814 \mathrm{~B} \\
50\end{array}$ & $\begin{array}{l}\text { minus } \\
\text { minus } \\
\text { minus }\end{array}$ & $\begin{array}{l}153 \mathrm{R} \\
153 \mathrm{R} \\
153 \mathrm{R}\end{array}$ & $\begin{array}{l}-155.86 \\
-146.68 \\
-147.62\end{array}$ & $\begin{array}{l}20.00 \\
19.86 \\
19.99\end{array}$ & $\begin{array}{l}19.92 \\
19.88 \\
19.96\end{array}$ \\
\hline $\begin{array}{c}814 \mathrm{~B} \\
50\end{array}$ & $\begin{array}{l}\text { minus } \\
\text { minus }\end{array}$ & $\begin{array}{l}752 \\
752\end{array}$ & $\begin{array}{r}+9.35 \\
+8.46\end{array}$ & $\begin{array}{l}19.95 \\
19.82\end{array}$ & $\begin{array}{l}19.97 \\
19.78\end{array}$ \\
\hline 50 & minus & $814 \mathrm{~B}$ & -1.03 & 19. 98 & 19.95 \\
\hline \multicolumn{4}{|c|}{ Mean of all temperatures.. } & \multicolumn{2}{|c|}{19.95} \\
\hline
\end{tabular}

a Interval nominally correct at $0^{\circ} \mathrm{C}$. b Interval nominally correct at $20^{\circ} \mathrm{C}$

45 residuals range from 0.02 to $0.20 \mu$ and the average, neglecting sign, is $0.08 \mu$. The probable error of the calculated value of the differences in the corrections between any two bars, $r$, is given by the formula ${ }^{3}$

$$
r=0.6745 \sqrt{\frac{\sum v^{2}}{\frac{N}{N_{i}}\left(N-N_{i}\right)}},
$$

where $\sum v^{2}$ is the sum of the squares of the residuals; $N$, the number of observational equations; and $N_{i}$, the number of unknowns. In the example considered, $N_{i}$ is equal to 9 and $N$ equal to 45 . For the case given in table $3, r$ is calculated to be \pm 0.03 .

3 T. W. Wright and J. F. Hayford, The adjustment of observations, p. 133, 137, 143, (1906).
During the period from 1933 to 1953, inclusive, seven series of determinations of the corrections to different groups of the 10-m bars under consideration were made. These determinations were made with groups of $7,6,7,8,9,6$, and 10 bars. All observations were made at approximately $20^{\circ} \mathrm{C}$, and the results reduced to $20^{\circ} \mathrm{C}$. The reductions of the observations were carried out by the method of least squares in all cases. The corrections to the total lengths of the bars, together with the new corrections for the prototype meter bars determined at the BIPM and authorized in 1933 by the Eighth General (International) Conference on Weights and Measures, are given in table 4.

The results of any auxiliary comparisons, made primarily because they served as checks in the interim between fundamental determinations, are not included in the table.

Several points should be noted in considering the data in table 4 . The seven values determined for the corrections to meter 4 are consistently smaller than the value reported by BIPM, whereas 6 of the 7 values determined for meter 21 and 4 of the 5 values determined for meter 12 , before regraduation, are larger than the values reported by BIPM. The differences between the corrections obtained by by NBS and those reported by BIPM for prototype meters 4,12 , and 21 are $-0.22,+0.22$, and $+0.15 \mu$, respectively. If we disregard the 1936 and 1938 values for meters 12 and 21 , respectively, the maximum range in the NBS corrections is $0.25 \mu$. The maximum range in the corrections for meter 4 is $0.22 \mu$.

Figure 2 shows the change in the determined correction to the total length of each of the two prototype meter bars, 4 and 21, from 1933 to 1953 , inclusive, and of meter 12 from 1933 to 1947, inclusive, and from 1949 to 1953 , inclusive.

From the above data it appears that there is considerable evidence that these three bars may have changed in length, two lengthening and one shortening, by about $0.2 \mu$ since first received. It is rather difficult to state to what extent the differences between the BIPM and NBS values represent changes in the actual length of the bars. As the measurements at the NBS were made under most favorable conditions and with extreme care, it is believed that the NBS is justified in using the latest determinations instead of those obtained several decades ago, as representing the true value for the corrections to be applied to the respective meter bars when calibrating line standards of length submitted to the Bureau.

Referring again to table 4 , it will be noted that the five laboratory standards of length, meters 39 , $153 \mathrm{R}, 752,814 \mathrm{~B}$, and 50, have changed in length during the 20-year period by a much greater amount than have the platinum-iridium meters. The three nickel-steel meters, $39,153 \mathrm{R}$, and $814 \mathrm{~B}$, and stainless steel meter 50 have continually elongated during this period, but Fix Invar meter 752 has shortened. The magnitudes of the changes in length between successive determinations, however, have generally 
TABLE 3. Calculations of corrections to meter bars at $20^{\circ} \mathrm{C}$

(1953 series of comparisons, using all 45 values for observed differences)

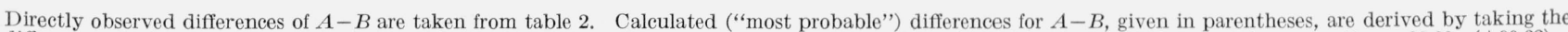

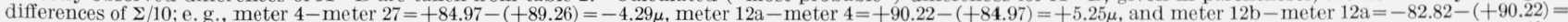

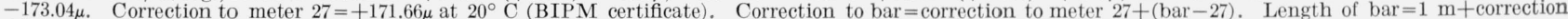
All values expressed in microns.

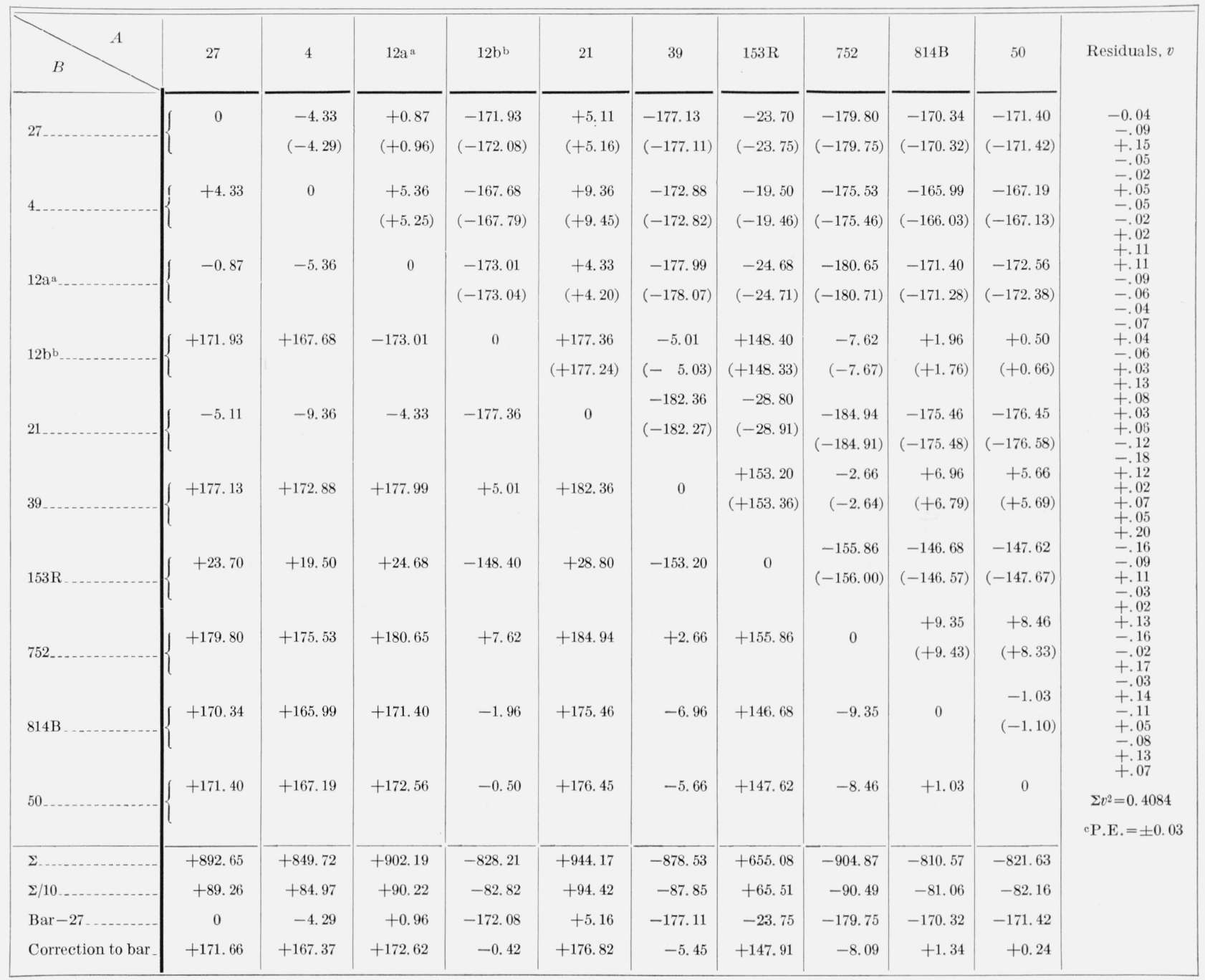

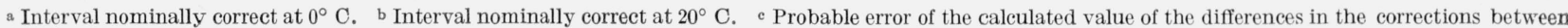
any two bars.

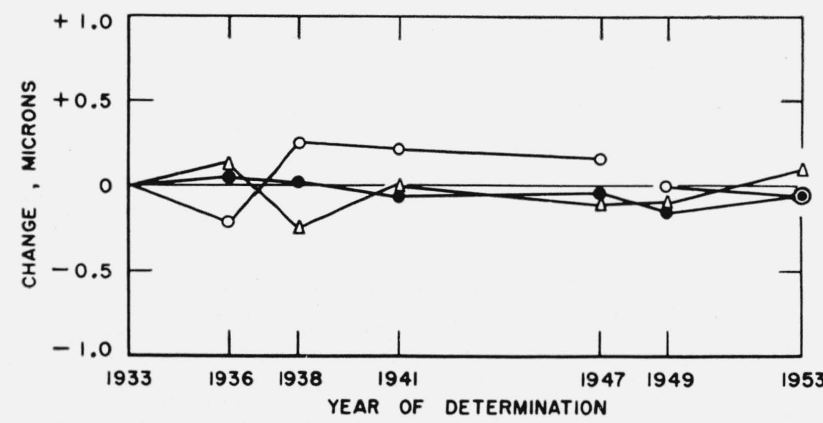

Figure 2. Apparent change in lengths of bars.

All values from fundamental determinations. - Meter 4; $\bigcirc$, meter 12; $\Delta$, meter 21 . 
TABLE 4. BIPM and NBS determinations of corrections to meter bars

(1933 to 1953 series of comparisons)

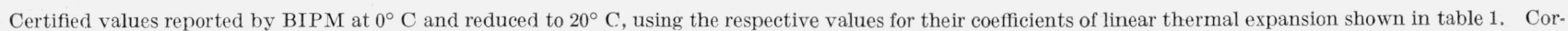
rection to bar $=$ correction to meter $27+($ bar -27$)$. All values expressed in microns.

\begin{tabular}{|c|c|c|c|c|c|c|c|c|c|c|c|c|c|c|c|}
\hline \multirow{3}{*}{ Meter bars } & \multicolumn{9}{|c|}{ Correction at $20^{\circ} \mathrm{C}$} & \multicolumn{6}{|c|}{ Differences } \\
\hline & \multirow{2}{*}{$\begin{array}{c}\text { BIPM } \\
1933\end{array}$} & \multicolumn{8}{|c|}{ NBS } & \multirow{2}{*}{$\begin{array}{l}\text { Mean } \\
\text { NBS- } \\
\text { BIPM }\end{array}$} & \multirow{2}{*}{$\begin{array}{c}\text { NBS } \\
1953- \\
1933\end{array}$} & \multirow{2}{*}{$\begin{array}{c}\text { NBS } \\
1953- \\
1938\end{array}$} & \multirow{2}{*}{$\begin{array}{c}\text { NBS } \\
1953- \\
1947\end{array}$} & \multirow{2}{*}{$\begin{array}{c}\text { NBS } \\
1953- \\
1949\end{array}$} & \multirow{2}{*}{$\begin{array}{c}\text { NBS } \\
1947- \\
1933\end{array}$} \\
\hline & & 1933 & 1936 & 1938 & 1941 & 1947 & 1949 & 1953 & Mean & & & & & & \\
\hline $27 \ldots \ldots$ & +171.66 & +171.66 & & & +171.66 & +171.66 & +171.66 & +171.66 & +171.66 & 0.00 & 0.00 & & & & \\
\hline $4(1874)$ & +167.62 & +167.44 & +167.50 & +167.44 & +167.36 & +167.39 & +167.28 & +167.37 & +167.40 & -.22 & -.07 & & & & \\
\hline 12 a $(1874)$ & +176.09 & +176.23 & +176.02 & +176.48 & +176.45 & +176.39 & (b) & (b) & +176.31 & +.22 & - & & & & +0.16 \\
\hline $\begin{array}{l}12 \mathrm{a} c(1874) \\
12 \mathrm{~b} d(1874)\end{array}$ & (n) & - & - & - & - & (n) & $\begin{array}{r}+172.59 \\
-0.29\end{array}$ & $\begin{array}{r}+172.62 \\
-0.42\end{array}$ & $\begin{array}{r}\mathrm{e}+172.60 \\
-0.36\end{array}$ & 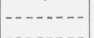 & - & & & $\begin{array}{r}+0.03 \\
-.13\end{array}$ & - nn \\
\hline $21 \ldots$ & +176.56 & +176.74 & +176.88 & +176.48 & +176.72 & +176.64 & +176.67 & $\begin{array}{r}0.72 \\
+176.82\end{array}$ & $\begin{array}{r}-0.50 \\
+176.71\end{array}$ & +0.15 & +0.08 & & & - & (n) \\
\hline $39 \ldots$ & & -10.13 & -9.17 & -8.42 & -8.00 & -6.66 & & -5.45 & & & +4.68 & & & $\ldots$ & -...... \\
\hline $153 \mathrm{R}$ & & +146.32 & +146.77 & +147.28 & +147.38 & +147.74 & +147.82 & +147.91 & & & +1.59 & & & & - \\
\hline 752 & & -0.95 & -2.73 & $\begin{array}{l}-3.23 \\
-0.56\end{array}$ & $\begin{array}{l}-4.97 \\
-0.04\end{array}$ & $\begin{array}{l}-7.05 \\
+110\end{array}$ & - & $\begin{array}{l}-8.09 \\
+1.34\end{array}$ & & - n & -7.14 & +190 & & & - non \\
\hline $50 \ldots$ & & (n) & (-.............. & ..... & $-0.0 t$ & -0.30 & (1) & $\begin{array}{r}+1.34 \\
+0.24\end{array}$ & & & 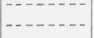 & (1...... & +0.54 & $-\cdots$ & -..... \\
\hline Probable error $\mathrm{f}$ & - & \pm 0.05 & \pm 0.11 & \pm 0.04 & \pm 0.02 & \pm 0.02 & \pm 0.03 & \pm 0.03 & & & & & & & $\ldots$ \\
\hline
\end{tabular}

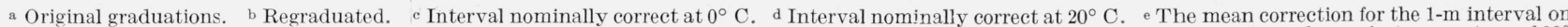

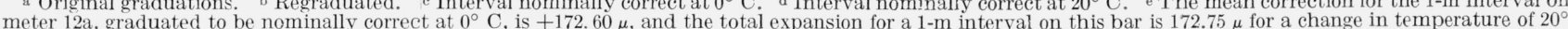
$\mathrm{C}$ : hence, the correction to the interval is $-0.15 \mu$ at $0^{\circ} \mathrm{C}$. $\mathrm{f}$ Probable error of the calculated value of the differences in the corrections between any two bars.

tended to decrease during the period from 1933 to 1953 , as shown in figure 3 .

How long a period might be required for these standards to become sufficiently stable to eliminate frequent standardizations is difficult to estimate. These laboratory standards are frequently used, between their restandardization, for measurements of moderate precision, where the changes in length over a comparatively short period of time are not significant. When they are used in measurements of the highest precision, they are compared with at least one platinum-iridium standard as a check on their assigned corrections.

The changes in the corrections during the periods between 1933 and 1938, 1938 and 1947, and 1947 and 1953 , are shown in table 5 .

Meter 39 is one of the first laboratory standards obtained by NBS, and it is of interest to note the average yearly change in length over a period of nearly a half century. The changes in length for this bar during the period from 1907 to 1953 are shown in figure 4 . The average changes in length per year, for the first 4, the following 10, and the last 32 years, are +1.2 , +0.6 , and $+0.2 \mu$, respectively. This shows that the magnitude of the changes in length is gradually becoming smaller.

TABLE 5. Length changes of meter bars

\begin{tabular}{|c|c|c|c|}
\hline \multirow{2}{*}{ Meter bars } & \multicolumn{3}{|c|}{ A verage changes per year } \\
\hline & $\begin{array}{c}1933 \text { to } \\
1938\end{array}$ & $\begin{array}{c}1938 \text { to } \\
1947\end{array}$ & $\begin{array}{c}1947 \text { to } \\
1953\end{array}$ \\
\hline $\begin{array}{l}39 \\
153 \mathrm{R} \\
752 \\
814 \mathrm{~B} \\
50\end{array}$ & \begin{tabular}{c}
$\mu$ \\
+0.3 \\
+.2 \\
.- .5 \\
\hdashline..- \\
\hdashline...
\end{tabular} & $\begin{array}{r}\mu \\
+0.2 \\
+.1 \\
+.4 \\
+.2 \\
-. . .\end{array}$ & $\begin{array}{r}\mu \\
+0.2 \\
<+.1 \\
-.2 \\
<+.1 \\
+.1\end{array}$ \\
\hline
\end{tabular}

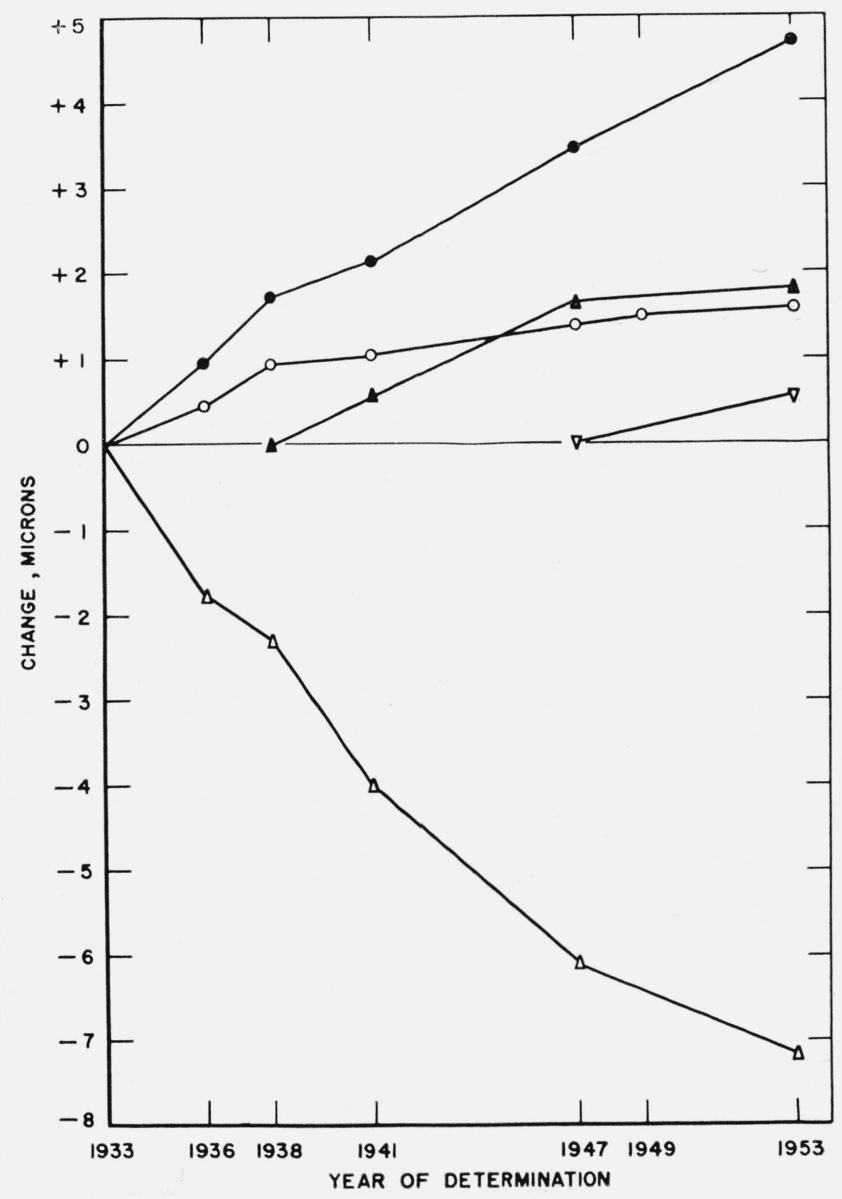

Figure 3. Change in lengths of bars.

All values from fundamental determinations. $\triangle$, meter $752 ; \mathbf{\Lambda}$, meter $814 \mathrm{~B} ; \nabla$, meter 50 . 


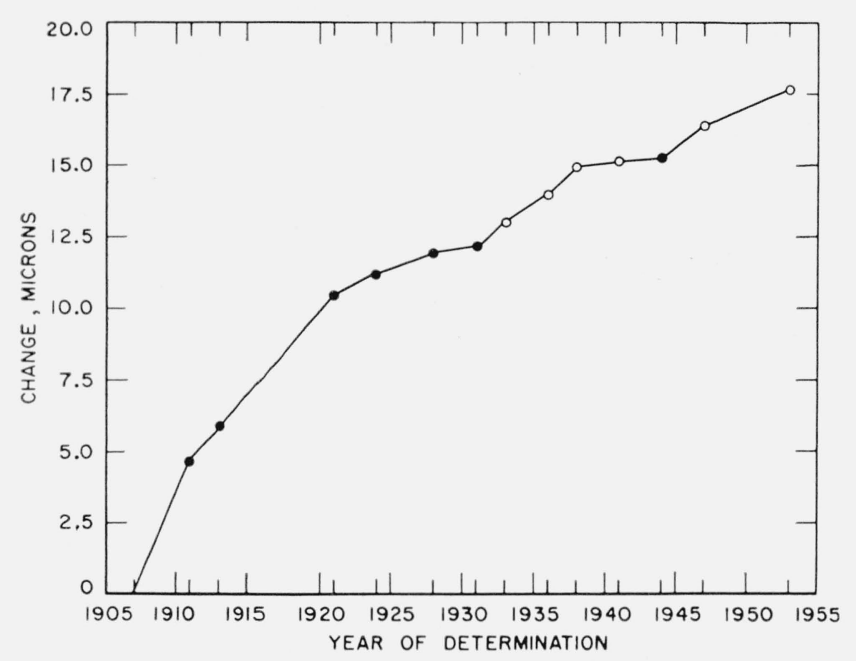

Figure 4.-Change in length of meter 39.

$\bigcirc$, From fundamental determinations; , from check determinations.

As the work required to observe and determine 45 values for the differences between the lengths of a group of 10 standards is rather laborious and consumes considerable time, it was decided to use the information obtained in the 1952 and 1953 series of comparisons for a study of the possibility of using fewer measurements for future intercomparisons of the same number of standards.

According to a scheme, ${ }^{4}$ calculations were made by using 30,25 , and 15 directly observed differences with the remaining differences computed from the observed values. The reduction of these differences, observed and computed, by the method of least squares was carried out by the use of forms (see footnote 2 ) shown in tables 6,7 , and 8 .

The scheme for using 30 directly observed differences and selecting the remaining 15 to be computed is as follows:

Arrange the numbers of the $10-\mathrm{m}$ bars as shown below.

$\begin{array}{rrrrr}* & 27 & 4 & 12 \mathrm{a} & 12 \mathrm{~b} \\ 27 & * & 21 & 39 & 153 \mathrm{R} \\ 4 & 21 & * & 752 & 814 \mathrm{~B} \\ 12 \mathrm{a} & 39 & 752 & * & 50 \\ 12 \mathrm{~b} & 153 \mathrm{R} & 814 \mathrm{~B} & 50 & *\end{array}$

Then cancel out the rows and columns that contain the number 27 ; this leaves the numbers $752,814 \mathrm{~B}$, and 50 as the serial numbers of the bars whose differences from meter 27 are to be computed. Restore the rows and columns and next cancel out the rows and columns that contain number 4 ; this then leaves the numbers $39,153 \mathrm{R}$, and 50 as the numbers of the bars whose differences from meter 4 are to be computed. This procedure is continued until each number has been cancelled out of its

\footnotetext{
4 W. J. Youden and W, S. Connor, New experimental designs for paired observations, J. Research NBS 53, 191 (1954) RP2532.
}

respective rows and columns and until all the differences between the 15 pairs of bars, whose differences are to be computed from directly observed differences, are determined. To compute these differences, the following method, illustrated by $752-27$, was used. First, the mean of the differences between 752 and each of the other bars with which it was directly compared and for which there is a corresponding directly observed comparison of that other bar with 27 was found. Next, the mean of the differences between 27 and each of the others with which it was compared, and for which there is a corresponding directly observed comparison of that other bar with 752 , was found. Finally, the mean values were added algebraically. This is the computed value for $752-27$, or $-179.82 \mu$, as is shown in brackets in table 6 . The other bracketed figures shown in table 6 were computed in a similar manner. All further computations to determine the corrections to the bars in this case are the same as in table 3.

The scheme for selecting and using 25 directly observed differences and for leaving the remaining 20 differences to be computed is as follows:

Arrange the numbers of the 10 bars as shown below.

$\begin{array}{lcccrc}\text { Group 1_. } & 27 & 4 & 12 \mathrm{a} & 12 \mathrm{~b} & 21 \\ \text { Group 2 _ _ } & 39 & 153 \mathrm{R} & 752 & 814 \mathrm{~B} & 50\end{array}$

The 25 directly observed differences to be used are those which are indicated by subtracting each of the numbers in group 1 from each of the numbers in group 2 , i. e., $39-27,153 \mathrm{R}-27,752-27,814 \mathrm{~B}-27$, $50-27, \ldots, 50-21$. The remaining 20 differences are computed in the same manner that was used when 30 directly observed differences were used, and are the bracketed figures shown in table 7. All further computations to determine the corrections to the bars in this case are the same as in table 3 .

The scheme for using 15 directly observed differences and computing the remaining 30 differences is the opposite of the scheme for which the 30 directly observed differences were used and the remaining 15 computed. The 30 computed differences were obtained in the same manner that was used where 15 and 20 differences were determined, and are the bracketed figures shown in table 8. All further computations to determine the corrections to the bars in this case are the same as in table 3 .

In computing the probable errors in tables 6,7 , and 8 , the same formula (see footnote 3 ) was used as in table 3. This was done for simplicity, although the probable errors thus obtained may be somewhat too small. Alternative methods for computing the differences and probable error are given by Youden and Connor (see footnote 4).

The corrections to the bars obtained in the calibration in which all differences were directly observed, and those obtained when only 30,25 , and 15 were directly observed, are tabulated in table 9 . The corrections to the various bars are in good agreement, even though a lesser number of direct differences were observed. This will be true only when all the 
observed differences in length between bars are accurately determined.

The values in columns 6 to 8 of table 9 were obtained by taking differences between the corresponding values in columns 3 and 2,4 and 2 , and 5 and 2, respectively. The average difference in the corrections (columns 6 to 8 ) increases with decrease in the number $(30,25$, and 15) of directly observed differences. The conclusion is that in the comparison of basic standards, a full calibration, where all the differences between bars are directly observed, may be justified. However, for secondary standards or others submitted for calibration, a lesser number of direct comparisons should be sufficient.

TABLE 6. Calculations of corrections to meter bars at $20^{\circ} \mathrm{C}$

(1953 series of comparisons, using 30 values for observed differences)

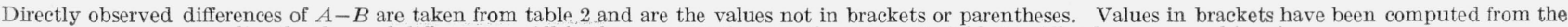
directly observed differences. All further computations are the same as in table 3 . All values expressed in microns,

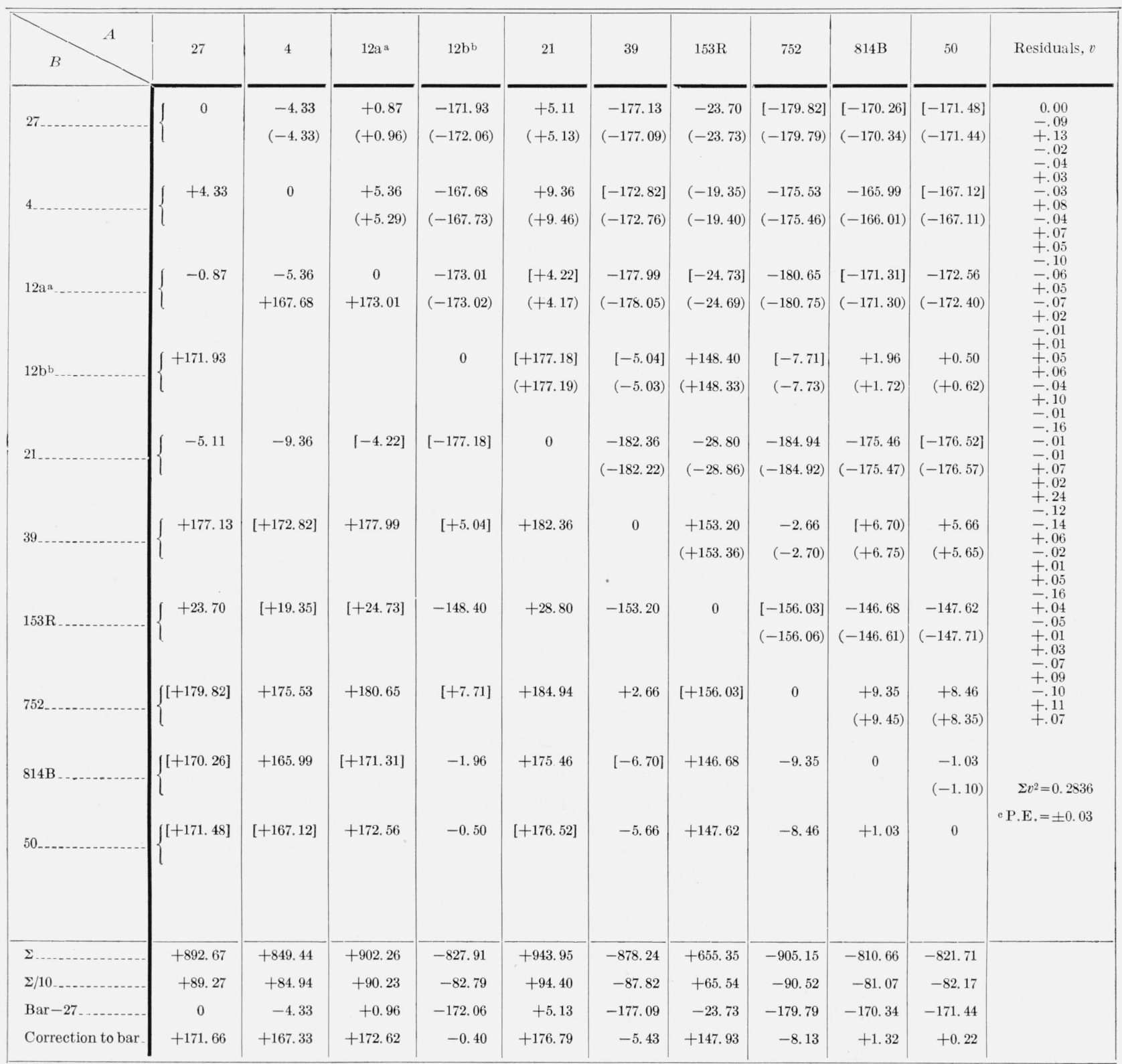

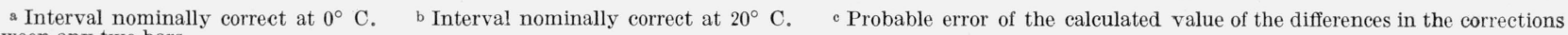
between any two bars. 
TABLE 7. Calculations of corrections to meter bars at $20^{\circ} \mathrm{C}$.

(1953 series of comparisons, using 25 values for observed differences).

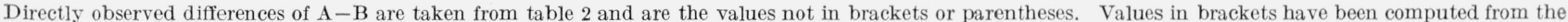
directly observed differences. All further computations are the same as in table 3. All values expressed in microns.

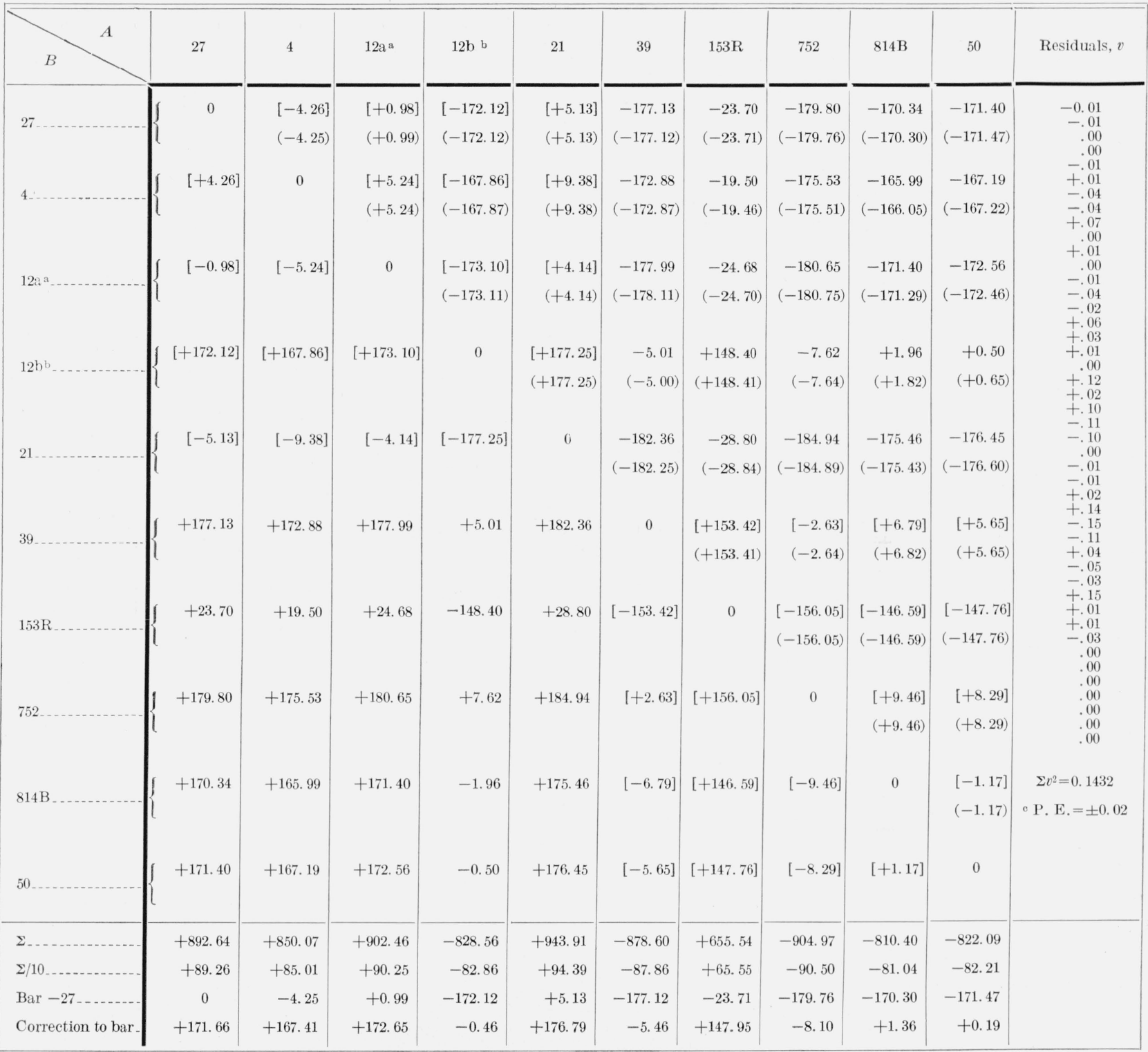

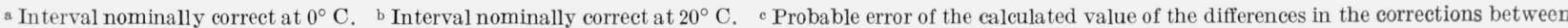
any two bars. 
TABLE 8. Calculations of corrections to meter bars at $20^{\circ} \mathrm{C}$.

(1953 series of comparisons, using 15 values for observed differences)

Directly observed differences of $A-B$ are taken from table 2 and are the values not in brackets or parentheses. Values in brackets have been computed from the directly observed differences. All further computations are the same as in table 3 . All values expressed in microns.

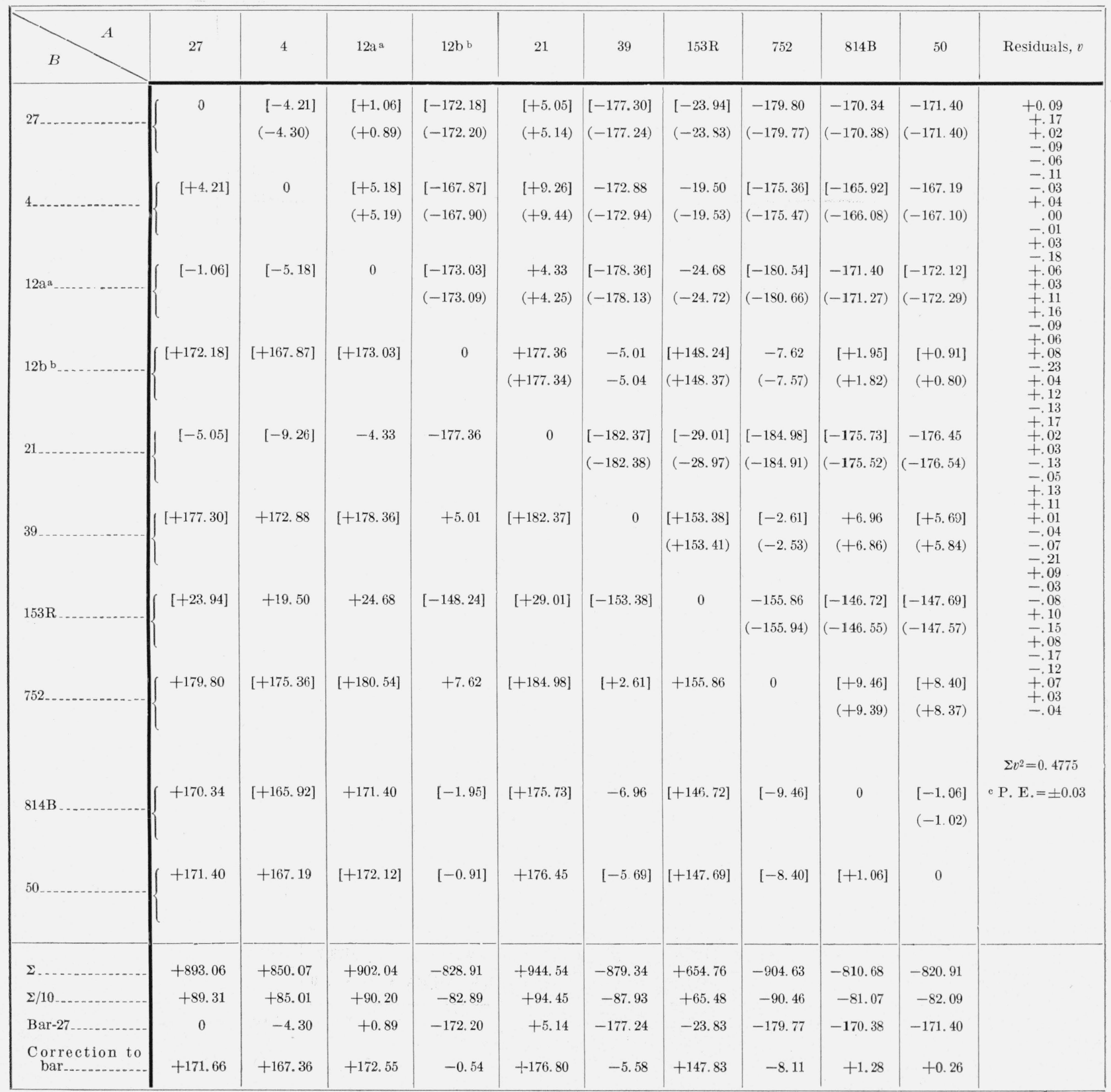

a Interval nominally correct at $0^{\circ} \mathrm{C} . \quad$ b Interval nominally correct at $20^{\circ} \mathrm{C}$. between any two bars. 
TABLE 9. Summary of corrections to the total length of meter bars, using different numbers of directly observed differences

(1953 series of comparisons)

\begin{tabular}{|c|c|c|c|c|c|c|c|}
\hline 1 & 2 & 3 & 4 & 5 & 6 & 7 & 8 \\
\hline \multirow{2}{*}{$\begin{array}{l}\text { Meter } \\
\text { bars }\end{array}$} & \multicolumn{4}{|c|}{$\begin{array}{l}\text { Corrections at } 20^{\circ} \mathrm{C} \text { for various } \\
\text { numbers of direct differences }\end{array}$} & \multicolumn{3}{|c|}{$\begin{array}{l}\text { Differences in cor- } \\
\text { rections }\end{array}$} \\
\hline & 45 & 30 & 25 & 15 & $30-45$ & $25-45$ & $15-45$ \\
\hline $\begin{array}{l}27 \\
12 \mathrm{a}^{\mathrm{a}}- \\
12 \mathrm{~b}^{\mathrm{b}}- \\
21\end{array}$ & $\begin{array}{r}\mu \\
+171.66 \\
+167.37 \\
+172.62 \\
-0.42 \\
+176.82\end{array}$ & $\begin{array}{r}\mu \\
+171.66 \\
+167.33 \\
+172.62 \\
-0.40 \\
+176.79\end{array}$ & $\begin{array}{r}\mu \\
+171.66 \\
+167.41 \\
+172.65 \\
-0.46 \\
+176.79\end{array}$ & $\begin{array}{r}\mu \\
+171.66 \\
+167.36 \\
+172.55 \\
-0.54 \\
+176.80\end{array}$ & $\begin{array}{c}\mu \\
0 \\
-0.04 \\
.00 \\
+.02 \\
-.03\end{array}$ & $\begin{array}{c}\mu \\
0 \\
+0.04 \\
+.03 \\
-.04 \\
-.03\end{array}$ & $\begin{array}{l}\mu \\
0 \\
-0.01 \\
-.07 \\
-.12 \\
-.02\end{array}$ \\
\hline $\begin{array}{l}39 \\
153 \mathrm{R}_{-} \\
752 \\
814 \mathrm{~B}_{-} \\
50\end{array}$ & $\begin{array}{r}-5.45 \\
+147.91 \\
-8.09 \\
+1.34 \\
+0.24\end{array}$ & $\begin{array}{r}-5.43 \\
+147.93 \\
-8.13 \\
+1.32 \\
+0.22\end{array}$ & $\begin{array}{r}-5.46 \\
+147.95 \\
-8.10 \\
+1.36 \\
+0.19\end{array}$ & $\begin{array}{r}-5.56 \\
+147.83 \\
-8.11 \\
+1.28 \\
+0.26\end{array}$ & $\begin{array}{l}+.02 \\
+.02 \\
-.04 \\
-.02 \\
-.02\end{array}$ & $\begin{array}{l}-.01 \\
+.04 \\
-.01 \\
+.02 \\
-.05\end{array}$ & $\begin{array}{l}-.11 \\
-.08 \\
-.02 \\
-.06 \\
+.02\end{array}$ \\
\hline $\mathrm{AV}$ & & & & & \pm 0.02 & \pm 0.03 & \pm 0.05 \\
\hline
\end{tabular}

a Interval nominally correct at $0^{\circ} \mathrm{C}$.

b Interval nominally correct at $20^{\circ} \mathrm{C}$.

\section{Calibration of the Subintervals}

Methods for the calibration of the subintervals of a standard of length have been described in Bureau Circular 329, Calibration of a Divided Scale, by Lewis V. Judson. In the recent calibrations of the subdivided meter bars, the methods described in Circular 329 have been used. In certain cases the method ${ }^{5}$ of double or cross calibration has been used.

The calibration of the subintervals of subdivided meter bars $4,39,153 \mathrm{R}, 752$, and $814 \mathrm{~B}$ was carried out in four steps, namely, the decimeter intervals, the centimeter intervals of all of the decimeter intervals, the millimeter intervals of the $1-$ and $92-\mathrm{cm}$ intervals, and the $1 / 10-\mathrm{m}$ intervals at each end of the bars.

Because of these calibrations, it is possible to compare lengths from $0.1 \mathrm{~mm}$ up to and including $1 \mathrm{~m}$ with calibrated intervals on any of these five standards.

The results are expressed as "elements of calibration", that is, the corrections which the subintervals will have at a temperature at which the whole interval has its nominal length. Thus, it is only necessary to distribute proportionately any newly determined total correction to the elements of calibration in order to obtain the new corrections to the subintervals.

\subsection{Calibration of the Decimeter Intervals}

The computed values for the several elements of calibration of the decimeter intervals of the 5 meter bars are given in table 10 . The probable errors of the calculated values for the elements of calibration

${ }^{5}$ C. E. Guillaume, L’étallonage des échelles divisées, Travaux et Mémoires du Bureau International des Poids et Mesures 13, 1 (1907).
TABLE 10. Elements of calibration of meter bars to decimeters (1953 series of calibrations)

Elements of calibration $=$ corrections to intervals, assuming that the meter bars have their nominal lengths. Relative length of interval=nominal length + element of calibration.

\begin{tabular}{|c|c|c|c|c|c|}
\hline \multirow{2}{*}{ Interval } & \multicolumn{5}{|c|}{ Elements of calibration of meter bars- } \\
\hline & 4 a & 39 & $153 \mathrm{R}$ & 752 & a $814 \mathrm{~B}$ \\
\hline $\begin{array}{l}0 \text { to } 1 \\
0 \text { to } 2 \\
0 \text { to } 3 \\
0 \text { to } 4 \\
0 \text { to } 5\end{array}$ & $\begin{array}{r}\mu \\
-0.46 \\
-3.16 \\
+0.06 \\
-.60 \\
-2.36\end{array}$ & $\begin{aligned} & \mu \\
- & 7.36 \\
- & 1.39 \\
+ & 0.98 \\
+ & 2.26 \\
- & 1.61\end{aligned}$ & $\begin{aligned} & \mu \\
+ & 1.41 \\
+ & 3.86 \\
+ & 3.51 \\
+ & 4.09 \\
+ & 5.36\end{aligned}$ & $\begin{aligned} & \mu \\
+ & -1.91 \\
+ & 4.18 \\
+ & 3.60 \\
+ & 2.43 \\
+ & 1.86\end{aligned}$ & $\begin{aligned} & \mu \\
&-0.76 \\
&-.54 \\
&-.74 \\
&-.88 \\
&-.48\end{aligned}$ \\
\hline $\begin{array}{l}0 \text { to } 6 \\
0 \text { to } 7 \\
0 \text { to } 8 \\
0 \text { to } 9 \\
0 \text { to } 10\end{array}$ & $\begin{array}{r}-2.28 \\
-1.58 \\
+0.08 \\
-1.64 \\
0.00\end{array}$ & $\begin{array}{r}+2.12 \\
-0.06 \\
-5.87 \\
+0.94 \\
.00\end{array}$ & $\begin{array}{r}+2.37 \\
+2.82 \\
+4.84 \\
+2.82 \\
\quad 0.00\end{array}$ & $\begin{array}{r}+1.87 \\
+1.78 \\
+0.60 \\
+.50 \\
\quad .00\end{array}$ & $\begin{array}{r}-.94 \\
-.14 \\
-1.56 \\
-1.25 \\
0.00\end{array}$ \\
\hline Probable error range_ & $\begin{array}{c} \pm 0.02 \\
\text { to } \\
\pm 0.03\end{array}$ & $\begin{array}{l} \pm 0.02 \\
\text { to } \\
\pm 0.03\end{array}$ & $\begin{array}{c} \pm 0.02 \\
\text { to } \\
\pm 0.03\end{array}$ & $\begin{array}{l} \pm 0.02 \\
\text { to } \\
\pm 0.03\end{array}$ & $\begin{array}{l} \pm 0.02 \\
\quad \text { to } \\
\pm 0.03\end{array}$ \\
\hline
\end{tabular}

a Mean of two calibrations.

are also shown. They were computed by using the formula ${ }^{6}$

$$
r_{x}=0.6745 \sqrt{\frac{\sum v^{2}}{K}},
$$

where $\sum v^{2}$ is the sum of the squares of the differences between the observed and computed values for the elements of calibration. As there are $(N-1)(N-2)$ equations of condition, $K$ is $[(N-1)(N-2)] / 2$, the value $r_{x}$ is the probable error of any $x$, and $x_{2}$ is the element of calibration to the first interval, $x_{3}$ is the element of calibration to the first two intervals, $x_{4}$ is the element of calibration to the first three intervals, etc.

That the differences between the observed and calculated values for the elements of calibretion are relatively small is indicated by the small probable errors, and that all of the measurements are apparently of nearly equal accuracy, regardless of the character of the lines on the various bars, is indicated by the probable errors being of the same magnitude.

It is of interest to note how well the values for the elements of calibration of the decimeter intervals determined during the past 25 vears agree with each other, and also to note the differences between the mean of these values and those obtained 50 years earlier. For this purpose, meter 39 was selected as an example, and the values determined in 1903 and those determined in 1928, 1931, 1932, 1947, and 1953 are given in table 11 .

The maximum deviations from the mean of five determinations from 1928 to 1953, inclusive, range from 0.04 to $0.17 \mu$, the average being $0.11 \mu$.

The probable cause of some of the large differences between the mean of the 1928 to 1953 determinations and those determined in 1903 is that the old Saxton

${ }^{6} \mathrm{O}$. J. Broch, Note sur l'étalonnage des sous-divisions d'une règle, Travaux et Mémoires du Bureau International des Poids et Mesures 5, 1 (1886). 
TABLE 11. Elements of calibration of meter 39 to decimeters

(1903 to 1953 series of calibrations)

Elements of calibration $=$ corrections to intervals, assuming that the meter bar has its nominal length. Relative length of interval=nominal length + element of calibration .

\begin{tabular}{|c|c|c|c|c|c|c|c|c|c|}
\hline \multirow{3}{*}{ Interval } & \multirow{2}{*}{\multicolumn{7}{|c|}{ Elements of calibration in the year }} & \multicolumn{2}{|c|}{ Differences } \\
\hline & & & & & & & & \multirow{2}{*}{$\begin{array}{l}\text { Maximum } \\
\text { deviation } \\
\text { from mean }\end{array}$} & \multirow{2}{*}{ Mean-1903 } \\
\hline & 1903 & 1928 & 1931 & 1932 & 1947 & 1953 & Mean & & \\
\hline $\begin{array}{l}0 \text { to } 1 \\
0 \text { to } 2 \\
0 \text { to } 3 \\
0 \text { to } 4 \\
0 \text { to } 5\end{array}$ & $\begin{aligned} & \mu \\
- & 7.43 \\
- & 1.45 \\
+ & 1.10 \\
+ & 2.29 \\
- & 1.48\end{aligned}$ & $\begin{aligned} & \mu \\
- & 7.20 \\
- & 1.41 \\
+ & 1.02 \\
+ & 2.29 \\
- & 1.59\end{aligned}$ & $\begin{aligned} & \mu \\
- & 7.38 \\
- & -4.48 \\
+ & 0.95 \\
+ & -2.25 \\
- & 1.56\end{aligned}$ & $\begin{aligned} & \mu \\
- & 7.38 \\
- & 1.52 \\
+ & 1.06 \\
+ & -2.30 \\
- & 1.54\end{aligned}$ & $\begin{aligned} & \mu \\
- & 7.20 \\
- & 1.28 \\
+ & 0.87 \\
+ & 2.23 \\
- & 1.48\end{aligned}$ & $\begin{aligned} & \mu \\
- & 7.36 \\
- & 1.39 \\
+ & 0.98 \\
+ & 2.26 \\
- & 1.61\end{aligned}$ & $\begin{aligned} & \mu \\
- & 7.30 \\
- & 1.42 \\
+ & 0.98 \\
+ & 2.27 \\
- & 1.56\end{aligned}$ & $\begin{array}{l}\mu \\
0.10 \\
.14 \\
.11 \\
.04 \\
.08\end{array}$ & $\begin{aligned} & \mu \\
&+ 0.13 \\
&+.03 \\
&-.12 \\
&-.02 \\
&-.08\end{aligned}$ \\
\hline $\begin{array}{l}0 \text { to } 6 \\
0 \text { to } 7 \\
0 \text { to } 8 \\
0 \text { to } 9 \\
0 \text { to } 10\end{array}$ & $\begin{array}{r}+2.42 \\
+0.29 \\
-6.13 \\
+0.72 \\
.00\end{array}$ & $\begin{array}{r}+2.27 \\
+0.05 \\
-5.75 \\
+0.97 \\
.00\end{array}$ & $\begin{array}{r}+2.25 \\
+0.02 \\
-5.85 \\
+0.95 \\
.00\end{array}$ & $\begin{array}{r}+2.25 \\
+0.02 \\
-5.84 \\
+0.86 \\
.00\end{array}$ & $\begin{array}{r}+2.36 \\
+0.22 \\
-5.62 \\
+1.11 \\
.00\end{array}$ & $\begin{array}{r}+2.12 \\
-0.06 \\
-5.87 \\
+0.94 \\
.00\end{array}$ & $\begin{array}{r}+2.25 \\
+0.05 \\
-5.79 \\
+0.97 \\
.00\end{array}$ & $\begin{array}{l}.13 \\
.17 \\
.17 \\
.14 \\
.00\end{array}$ & $\begin{array}{l}-.17 \\
-.24 \\
+.34 \\
+.25 \\
.00\end{array}$ \\
\hline Probable error range........................... & $\begin{array}{l} \pm 0.10 \text { to } \\
\pm 0.11\end{array}$ & $\begin{array}{l} \pm 0.03 \text { to } \\
\pm 0.04\end{array}$ & $\begin{array}{l} \pm 0.02 \text { to } \\
\pm 0.03\end{array}$ & $\begin{array}{l} \pm 0.02 \text { to } \\
\pm 0.03\end{array}$ & $\begin{array}{l} \pm 0.03 \text { to } \\
\pm 0.04\end{array}$ & $\begin{array}{l} \pm 0.03 \text { to } \\
\pm 0.04\end{array}$ & $\ldots$ & -..- & -.....- \\
\hline
\end{tabular}

comparator used in 1903 was not entirely adequate for the work. It is fortunate, however, that the values for the elements of calibration thereby determined are in fairly good agreement with those obtained by the use of more recent and better equipment.

\subsection{Calibration of the Centimeter Intervals}

In determining the elements of calibration to the centimeter subintervals, the double- or cross-calibration method was used, that is, a comparison of each interval with the others in all possible combinations; namely, the centimeter intervals of the first and sixth decimeters, those of the second and seventh, the third and eighth, the fourth and ninth, and the fifth and tenth.

\subsection{Calibration of the Millimeter Intervals}

The elements of calibration of the millimeter intervals of the centimeter intervals, 0 to $1 \mathrm{~cm}$ and 91 to $92 \mathrm{~cm}$, were obtained by the same method as was used to determine the elements of calibration of the centimeter subintervals.

For the sake of brevity the results of the determinations of the elements of calibration of the subintervals of only meter 4 are reported in this paper. The two NBS calibrations for the decimeter, centimeter, and millimeter subintervals on meter 4 , together with those reported in 1907 for the same subintervals by BIPM, are shown in table 12 .

The probable errors for the elements of calibration of any centimeter or millimeter subinterval range from \pm 0.03 to $\pm 0.07 \mu$, and were computed by the use of the formula ${ }^{\gamma}$

$$
r_{x}=0.6745 \frac{\sqrt{2}}{(N-1) \sqrt{N-1}} \sqrt{\sum v^{2}},
$$

7 T. W. Wright and J. F. Hayford, The adjustment of observations, p. 133 and 142 (1906); Dziobek, Ueber die Ermittelung der inneren Theilungsfehler zweier Maassstäbe nach der Methode des Durchschiebens, Wiss. Abhandl Kaiserlichen Normal-Aichungs-Kommission 4, 1 (1903).
TABLE 12. Elements of calibration of meter 4 to millimeters at $B I P M$ and $N B S$

(NBS 1953 series of calibrations)

Elements of calibration $=$ corrections to intervals, assuming that the meter bar has its nominal length. Relative length of interval=nominal length+element of calibration.

\begin{tabular}{|c|c|c|c|c|c|c|}
\hline \multirow{2}{*}{$\begin{array}{l}\text { Interval } \\
\qquad \begin{array}{c}m m \\
0 \text { to } 1 \\
0 \text { to } 2\end{array}\end{array}$} & \multicolumn{3}{|c|}{ Elements of calibration } & \multirow{3}{*}{$\begin{array}{c}\text { NBS } \\
\text { mean a } \\
\\
\\
\mu \\
-0.07 \\
+.38 \\
-.62 \\
-.75 \\
-1.06\end{array}$} & \multirow{3}{*}{$\begin{array}{c}\text { NBS } \\
\text { maxi- } \\
\text { mum } \\
\text { deviation } \\
\text { from } \\
\text { mean }\end{array}$} & \multirow{3}{*}{$\begin{array}{c}\text { NBS- } \\
\text { BIPM } \\
\\
\\
\\
\mu \\
+0.1 \\
+.1 \\
+.2 \\
+.4 \\
+.2\end{array}$} \\
\hline & \multirow{2}{*}{$\begin{array}{c}\text { BIPM } \\
\mu \\
\mu .2 \\
+0.3 \\
+.8 \\
-1.1 \\
-1.3\end{array}$} & \multicolumn{2}{|c|}{ NBS } & & & \\
\hline $\begin{array}{l}\quad \mathrm{mm} \\
0 \text { to } 1 \\
0 \text { to } 2 \\
0 \text { to } 3 \\
0 \text { to } 4 \\
0 \text { to } 5 \\
\end{array}$ & & $\begin{array}{r}\mu \\
+0.01 \\
+. .42 \\
-.56 \\
-.72 \\
-1.06\end{array}$ & $\begin{array}{r}\mu \\
-0.15 \\
+. .34 \\
-.67 \\
-.78 \\
-1.05\end{array}$ & & & \\
\hline $\begin{array}{l}0 \text { to } 6 \\
0 \text { to } 7 \\
0 \text { to } 8 \\
0 \text { to } 9 \\
0 \text { to } 10\end{array}$ & $\begin{array}{l}-1.6 \\
-1.8 \\
-1.7 \\
-1.8 \\
-2.2\end{array}$ & $\begin{array}{l}-1.31 \\
-1.43 \\
-1.45 \\
-1.50 \\
-1.93\end{array}$ & $\begin{array}{l}-1.24 \\
-1.41 \\
-1.46 \\
-1.55 \\
-2.02\end{array}$ & $\begin{array}{l}-1.28 \\
-1.42 \\
-1.46 \\
-1.52 \\
-1.98\end{array}$ & $\begin{array}{l}.04 \\
.01 \\
.01 \\
.03 \\
.05\end{array}$ & $\begin{array}{r}+.3 \\
+.4 \\
+.2 \\
+.3 \\
+.2\end{array}$ \\
\hline $\begin{array}{l}0 \text { to } 20 \\
0 \text { go } 30 \\
0 \text { to } 40 \\
0 \text { to } 50 \\
0 \text { to } 60\end{array}$ & $\begin{array}{r}-2.5 \\
-2.4 \\
-0.8 \\
-.7 \\
-.9\end{array}$ & $\begin{array}{l}-2.20 \\
-2.30 \\
-1.03 \\
-0.96 \\
-1.12\end{array}$ & $\begin{array}{l}-2.37 \\
-2.37 \\
-1.09 \\
-0.90 \\
-1.22\end{array}$ & $\begin{array}{l}-2.28 \\
-2.34 \\
-1.06 \\
-0.93 \\
-1.17\end{array}$ & $\begin{array}{l}.09 \\
.04 \\
.03 \\
.03 \\
.05\end{array}$ & $\begin{array}{l}+.2 \\
+.1 \\
-.3 \\
-.2 \\
-.3\end{array}$ \\
\hline $\begin{array}{l}0 \text { to } 70 \\
0 \text { to } 80 \\
0 \text { to } 90 \\
0 \text { to } 100 \\
0 \text { to } 110\end{array}$ & $\begin{array}{r}-1.4 \\
-1.2 \\
-1.1 \\
-0.5 \\
-.6\end{array}$ & $\begin{array}{r}-1.60 \\
-1.52 \\
-1.24 \\
-0.42 \\
-.42\end{array}$ & $\begin{array}{r}-1.53 \\
-1.36 \\
-1.22 \\
-0.49 \\
-.62\end{array}$ & $\begin{array}{l}-1.56 \\
-1.44 \\
-1.23 \\
-0.46 \\
-.52\end{array}$ & $\begin{array}{l}.04 \\
.08 \\
.01 \\
.04 \\
.10\end{array}$ & $\begin{array}{r}-.2 \\
-.2 \\
-.1 \\
.0 \\
+.1\end{array}$ \\
\hline $\begin{array}{l}0 \text { to } 120 \\
0 \text { to } 130 \\
0 \text { to } 140 \\
0 \text { to } 150 \\
0 \text { to } 160\end{array}$ & $\begin{array}{l}-.4 \\
-1.4 \\
-1.0 \\
-2.0 \\
-3.7\end{array}$ & $\begin{array}{l}-.31 \\
-1.28 \\
-0.98 \\
-2.02 \\
-3.48\end{array}$ & $\begin{array}{r}-.53 \\
-\mathbf{1} .48 \\
-1.17 \\
-2.16 \\
-3.66\end{array}$ & $\begin{array}{r}-.42 \\
-1.38 \\
-1.08 \\
-2.09 \\
-3.57\end{array}$ & $\begin{array}{l}.11 \\
.10 \\
10 \\
.07 \\
.09\end{array}$ & $\begin{array}{r}.0 \\
-0 \\
-0.1 \\
-.1 \\
+.1\end{array}$ \\
\hline $\begin{array}{l}0 \text { to } 170 \\
0 \text { to } 180 \\
0 \text { to } 190 \\
0 \text { to } 200 \\
0 \text { to } 210\end{array}$ & $\begin{array}{l}-2.4 \\
-1.3 \\
-2.3 \\
-3.6 \\
-3.0\end{array}$ & $\begin{array}{l}-2.15 \\
-1.29 \\
-2.10 \\
-3.11 \\
-2.49\end{array}$ & $\begin{array}{l}-2.36 \\
-1.39 \\
-2.16 \\
-3.20 \\
-2.64\end{array}$ & $\begin{array}{l}-2.26 \\
-1.34 \\
-2.13 \\
-3.16 \\
-2.56\end{array}$ & $\begin{array}{l}.11 \\
.05 \\
.03 \\
.05 \\
.08\end{array}$ & $\begin{array}{r}+.1 \\
.0 \\
+.2 \\
+.4 \\
+.4\end{array}$ \\
\hline $\begin{array}{l}0 \text { to } 220 \\
0 \text { to } 230 \\
0 \text { to } 240 \\
0 \text { to } 250 \\
0 \text { to } 260\end{array}$ & $\begin{array}{l}-2.1 \\
-2.0 \\
-2.6 \\
-2.2 \\
-1.9\end{array}$ & $\begin{array}{l}-1.63 \\
-1.50 \\
-1.95 \\
-1.62 \\
-1.20\end{array}$ & $\begin{array}{l}-1.82 \\
-1.85 \\
-2.24 \\
-2.05 \\
-1.60\end{array}$ & $\begin{array}{l}-1.72 \\
-1.68 \\
-2.10 \\
-1.84 \\
-1.40\end{array}$ & $\begin{array}{l}.10 \\
.18 \\
.15 \\
.22 \\
.20\end{array}$ & $\begin{array}{l}+.4 \\
+.3 \\
+.5 \\
+.4 \\
+.5\end{array}$ \\
\hline $\begin{array}{l}0 \text { to } 270 \\
0 \text { to } 280 \\
0 \text { to } 290 \\
0 \text { to } 300 \\
0 \text { to } 310\end{array}$ & $\begin{array}{r}-2.0 \\
-2.6 \\
-1.8 \\
0.0 \\
+.4\end{array}$ & $\begin{array}{r}-1.41 \\
-2.16 \\
-1.24 \\
+0.12 \\
+.60\end{array}$ & $\begin{array}{r}-1.77 \\
-2.47 \\
-1.53 \\
+0.01 \\
+.58\end{array}$ & $\begin{array}{r}-1.59 \\
-2.32 \\
-1.38 \\
+0.06 \\
+.59\end{array}$ & $\begin{array}{l}.18 \\
.16 \\
.15 \\
.06 \\
.01\end{array}$ & $\begin{array}{r}+.4 \\
+.3 \\
+.4 \\
+.1 \\
+.2\end{array}$ \\
\hline $\begin{array}{l}0 \text { to } 320 \\
0 \text { to } 330 \\
0 \text { to } 340 \\
0 \text { to } 350 \\
0 \text { to } 360\end{array}$ & $\begin{array}{r}+.5 \\
+1.6 \\
+0.2 \\
-2.9 \\
-3.2\end{array}$ & $\begin{array}{r}+.77 \\
+2.02 \\
+0.27 \\
-2.63 \\
-2.73\end{array}$ & $\begin{array}{r}+.67 \\
+1.86 \\
+0.17 \\
-2.88 \\
-2.90\end{array}$ & $\begin{array}{r}+.72 \\
+1.94 \\
+0.22 \\
-2.76 \\
-2.82\end{array}$ & $\begin{array}{l}.05 \\
.08 \\
.05 \\
.13 \\
.09\end{array}$ & $\begin{array}{r}+.2 \\
+.3 \\
.0 \\
+.1 \\
+.4\end{array}$ \\
\hline
\end{tabular}


TABLE 12. Elements of calibration of meter 4 to millimeters at $B I P M$ and $N B S$-Continued

\begin{tabular}{|c|c|c|c|c|c|c|}
\hline \multirow{3}{*}{$\begin{array}{c}\text { Interval } \\
m m \\
0 \text { to } 370\end{array}$} & \multicolumn{3}{|c|}{ Elements of calibration } & \multirow{2}{*}{$\begin{array}{l}\text { NBS } \\
\text { mean a }\end{array}$} & \multirow{2}{*}{$\begin{array}{c}\text { NBS } \\
\text { maxi- } \\
\text { mum } \\
\text { deviation } \\
\text { from } \\
\text { mean }\end{array}$} & \multirow{2}{*}{$\begin{array}{l}\text { NBS- } \\
\text { BIPM }\end{array}$} \\
\hline & BIPM & \multicolumn{2}{|c|}{ NBS } & & & \\
\hline & $\stackrel{\mu}{-1} 7$ & $-1_{20}^{\mu}$ & $-1_{46}^{\mu}$ & $-1_{33}^{\mu}$ & ${ }_{13}^{\mu}$ & $\stackrel{\mu}{+}$ \\
\hline 0 to $380 \ldots$ & $\begin{array}{l}-1.1 \\
-0.3\end{array}$ & +0.06 & $\begin{array}{l}-1.40 \\
+0.07\end{array}$ & $\begin{array}{l}-1.00 \\
+0.06\end{array}$ & .01 & \\
\hline 0 to 390 & -.1 & +.17 & $\begin{array}{r}7 \\
+.20\end{array}$ & $\begin{array}{l}+.18 \\
+.18\end{array}$ & .02 & 3 \\
\hline & & -.59 & -.61 & -.60 & .01 & 2 \\
\hline 0 to $410 \ldots$ & -.7 & -.38 & -.53 & -.46 & .08 & +.2 \\
\hline 0 to $420 \ldots$ & -.4 & -.21 & -.21 & -.21 & .00 & +.2 \\
\hline 0 to $430 \ldots$ & & +.24 & +.18 & +.21 & .03 & \\
\hline 0 to 4 & +.4 & +.60 & +.57 & +.58 & .02 & \\
\hline 0 to $450 \ldots$ & -.2 & -.16 & -.10 & -.13 & .03 & \\
\hline 0 to $460 \ldots$ & +.2 & +.47 & +.24 & +.36 & .12 & +.2 \\
\hline 0 to $470 \ldots$ & -.4 & -.26 & -.44 & -.35 & .09 & \\
\hline & +.3 & +.48 & +.36 & +.42 & .06 & t. \\
\hline & 2.1 & -2.08 & -2.20 & -2.14 & .06 & \\
\hline & -2.3 & -2.28 & -2.43 & -2.36 & .08 & -.1 \\
\hline 0 to $510 \ldots$ & -1.5 & -1.28 & -1.38 & -1.33 & .05 & +.2 \\
\hline 0 to $520 \ldots$ & -0.7 & -0.50 & -0.57 & -0.54 & .04 & +.2 \\
\hline 0 to 5 & -1.9 & -1.81 & -1.80 & -1.80 & .01 & \\
\hline 0 to & -3.0 & -2.76 & -2.67 & -2.72 & .05 & + \\
\hline 0 to $550 \ldots$ & -2.5 & -2.25 & -2.21 & -2.23 & .02 & +.3 \\
\hline 0 to $560 \ldots$ & -2.1 & -1.80 & -1.76 & -1.78 & .02 & +.3 \\
\hline 0 to $570 \ldots$ & -2.5 & -2.32 & -2.22 & -2.27 & .05 & +.2 \\
\hline 0 to $580 \ldots$ & -2.1 & -2.83 & -2.80 & -2.82 & .02 & \\
\hline & -23 & -2.05 & -2.09 & -2.07 & .02 & + . \\
\hline & -2.5 & -2.22 & -2.35 & -2.28 & .07 & + \\
\hline 0 to $610 \ldots$ & -3.2 & -3.09 & -3.05 & -3.07 & .02 &.+ \\
\hline 0 to $620 \ldots$ & -3.9 & -3.61 & -3.67 & -3.64 & .03 & +.3 \\
\hline & -2.4 & -2.05 & 0 & -2.14 & .09 & 2 \\
\hline & -1.2 & -0.94 & -1. & -1.05 & .11 & \\
\hline & -1.2 & -.79 & -0.98 & -0.88 & .10 & +.3 \\
\hline 0 to 660 & -1.3 & -1.04 & -1.11 & -1.08 & .04 & +.2 \\
\hline 0 to $670 \ldots$ & +0.4 & +0.70 & +0.56 & +0.63 & .07 & +.2 \\
\hline & -2.6 & -2.21 & -2.29 & -2.2 & .04 & \\
\hline 0 to 6 & -3.1 & -2.83 & -2.80 & -2.82 & .02 & \\
\hline 0 to & -2.0 & -1.55 & -1.61 & -1.58 & .03 & \\
\hline 0 to $710 \ldots$ & -1.1 & -0.63 & -0.88 & -0.76 & .13 & +.3 \\
\hline 0 to 720 . & +0.7 & +1.24 & +1.00 & +1.12 & .12 & +.4 \\
\hline & & $\begin{array}{r}+0.14 \\
\end{array}$ & -0.04 & +0.05 & .09 & \\
\hline & -.3 & -.14 & -.2 & -.20 & & \\
\hline & -.6 & -.21 & -.43 & -.32 & & \\
\hline 0 to $760 \ldots$ & -.1 & +.02 & -.17 & -.08 & .10 & .0 \\
\hline 0 to $770_{\ldots}$ & +.7 & +.86 & +.70 & +.78 & .08 & +.1 \\
\hline & $\begin{array}{l}+.6 \\
+.8\end{array}$ & $\begin{array}{r}+.60 \\
+1.13\end{array}$ & $\begin{array}{r}+.5 \\
+9 \\
\end{array}$ & $\begin{array}{r}+.55 \\
+103\end{array}$ & .05 & $\begin{array}{r}.0 \\
+.2 \\
\end{array}$ \\
\hline & $\begin{array}{r}+.8 \\
.0\end{array}$ & $\begin{array}{l}+1.10 \\
+0.11\end{array}$ & $\begin{array}{r}+.9 \\
+.0\end{array}$ & $\begin{array}{r}1.00 \\
+0.08\end{array}$ & .03 & 1 \\
\hline 0 to $810 \ldots$ & +.7 & $\begin{array}{r}+11 \\
+.76\end{array}$ & +.75 & $\begin{array}{l}0.86 \\
+76\end{array}$ & .01 &.+ \\
\hline 0 to 820 . & -.5 & -.14 & -.34 & -.24 & .10 & +.3 \\
\hline & -1.5 & -1.35 & -1. & -1.4 & .10 & \\
\hline & -0.5 & -0.21 & -0.3 & -0. & .09 & \\
\hline & +.3 & +.53 & +.33 & +.43 & .10 & \pm \\
\hline 0 to $860 \ldots$ & -.4 & -.24 & -.38 & -.31 & .07 & t. \\
\hline 0 to $870 \ldots$ & -1.0 & -1.04 & -1.18 & -1.11 & .07 & -.1 \\
\hline & & 0.6 & & -0.6 & 02 & \\
\hline & -1.4 & -1.3 & -1 & -1.3 & & \\
\hline & 2.0 & -1.6 & -1.6 & -1.64 & & $一$ \\
\hline $\mathrm{C}$ to $910 \ldots$ & -3.1 & -2.99 & -2.79 & -2.89 & .10 & +.2 \\
\hline 0 to $911 \ldots$ & -3.1 & -3.12 & -2.77 & -2.94 & .18 & \\
\hline & $\begin{array}{l}-3.2 \\
-3.0\end{array}$ & $\begin{array}{l}-3.10 \\
-280\end{array}$ & $\begin{array}{l}-2.8 \\
-2.7\end{array}$ & $\begin{array}{l}-2.8 \\
-2.8\end{array}$ & .15 & + \\
\hline & $\begin{array}{l}-0.0 \\
-3.2\end{array}$ & $\begin{array}{l}-2.89 \\
-2.96\end{array}$ & -2.8 & $\begin{array}{l}-2.8 \\
-2.8\end{array}$ & $\begin{array}{r}.05 \\
08\end{array}$ & +.3 \\
\hline 0 to 915 - & -3.3 & -3.10 & $\begin{array}{l}-3.09 \\
-3.00\end{array}$ & -3.10 & .01 & +.2 \\
\hline 0 to $916 \ldots$ & -2.8 & -2.67 & -2.59 & -2.63 & .04 & t. \\
\hline & -3.0 & -2.73 & -2.7 & -2 . & .00 & \\
\hline & -3.0 & -2.78 & -2.7 & -2.7 & .02 & \\
\hline & -2.7 & -2.58 & -2.5 & -2.56 & & + \\
\hline 0 to $920 \ldots$ & -2.6 & -2.49 & -2.40 & -2.44 & .00 & +.2 \\
\hline 0 to 930 & -2.3 & -2.13 & -2.12 & -2.1 & & +.2 \\
\hline 0 to 940. & & -2.44 & -2.48 & -2.46 & .02 & \\
\hline & & -3.6 & -3.70 & -3.68 & .02 & \\
\hline & -2.6 & -2.48 & -2.47 & -2.48 & .01 & \\
\hline 0 to $970 \ldots$ & -1.7 & -1.63 & -1.56 & -1.60 & .04 & +.1 \\
\hline 0 to $980 \ldots$ & -1.8 & -1.68 & -1.65 & -1.66 & .02 & +.1 \\
\hline & $\begin{array}{r}-2.3 \\
0.0\end{array}$ & -2.08 & -1.98 & -2.03 & .05 & +.3 \\
\hline 0 to 1 & & 0.00 & 0.00 & 0.00 & .00 & 0.0 \\
\hline
\end{tabular}

where $\Sigma v^{2}$ is the sum of the squares of the differences between the observed and computed values for the elements of calibration, $N$, the number of subintervals into which any considered interval is divided, and $r_{x}$ is the probable error of the element of calibration of any subinterval.

The deviations from the mean of two determinations for all of the elements of calibration for meter 4 range from 0.00 to $0.22 \mu$, the average being $0.06 \mu$.

The discrepancies between the values originally reported by BIPM for these elements of calibration and the values determined by NBS vary from -0.3 to $+0.5 \mu$. However, over a period of years repeated determinations of the elements of calibration of the decimeter subintervals on meter 4 have shown highly consistent results, and it is indicated, therefore, that the NBS values are very nearly the present true values for all of the elements of calibration for the subintervals. Taking into consideration that the NBS values were determined by using a comparator of more modern design, with more accurate auxiliary equipment and under more favorable conditions than were available in 1907 at BIPM, it is believed that the NBS is justified in adopting these new values as representing more nearly the true values than those originally determined.

\subsection{Calibration of the One-tenth Millimeter Intervals}

The $1 / 10-\mathrm{mm}$ subintervals at each end of the meter bars were also calibrated by using the same doubleor cross-calibration method used in the calibration of the centimeter and millimeter subintervals. The

TABLE 13. Elements of calibration of the one-tenth millimeter intervals of meter 4

(NBS 1953 series of calibrations)

Elements of calibration $=$ corrections to intervals, assuming that the subdivided millimeter intervals have their nominal lengths. Relative length of interval= nominal length + element of calibration.

\begin{tabular}{|c|c|c|c|c|}
\hline \multirow{2}{*}{ Interval } & \multicolumn{2}{|c|}{ Elements of calibration } & \multirow{2}{*}{ Mean } & \multirow{2}{*}{$\begin{array}{l}\text { Deviation } \\
\text { from mean }\end{array}$} \\
\hline & First & Second & & \\
\hline $\begin{array}{l}m m \\
-1.0 \text { to } \\
-0.9 \\
-.8 \\
-.7 \\
-.6 \\
-.5\end{array}$ & $\begin{array}{c}\mu \\
-1.29 \\
-1.04 \\
-1.18 \\
-0.83 \\
-.43\end{array}$ & $\begin{array}{c}\mu \\
-1.34 \\
-1.07 \\
-1.26 \\
-1.03 \\
-0.56\end{array}$ & $\begin{array}{c}\mu \\
-1.32 \\
-1.06 \\
-1.22 \\
-0.93 \\
-.50\end{array}$ & $\begin{array}{c}\mu \\
0.03 \\
.02 \\
.04 \\
.10 \\
.07\end{array}$ \\
\hline $\begin{array}{r}-.4 \\
-.3 \\
-.2 \\
-.1 \\
.0\end{array}$ & $\begin{array}{l}-.33 \\
-.07 \\
-.07 \\
-.24 \\
.00\end{array}$ & $\begin{array}{l}-.40 \\
-.14 \\
-.06 \\
-.14 \\
.00\end{array}$ & $\begin{array}{l}-.36 \\
-.10 \\
-.06 \\
-.19 \\
.00\end{array}$ & $\begin{array}{l}.04 \\
.04 \\
.01 \\
.05 \\
.00\end{array}$ \\
\hline $\begin{array}{l}1000.0 \text { to } \\
1000.1 \\
1600.2 \\
1000.3 \\
1000.4 \\
1000.5\end{array}$ & $\begin{array}{r}-0.40 \\
-.04 \\
-.27 \\
-.71 \\
-.60\end{array}$ & $\begin{array}{r}-0.45 \\
-.04 \\
-.41 \\
-.66 \\
-.58\end{array}$ & $\begin{array}{r}-0.42 \\
-.04 \\
-.34 \\
-.68 \\
-.59\end{array}$ & $\begin{array}{l}0.03 \\
.00 \\
.07 \\
.03 \\
.01\end{array}$ \\
\hline $\begin{array}{l}1000.6 \\
1000.7 \\
1000.8 \\
1000.9 \\
1001.0\end{array}$ & $\begin{array}{l}-.45 \\
-.37 \\
-.30 \\
-.29 \\
.00\end{array}$ & $\begin{array}{l}-.42 \\
-.37 \\
-.37 \\
-.30 \\
.00\end{array}$ & $\begin{array}{l}-.44 \\
-.37 \\
-.34 \\
-.30 \\
.00\end{array}$ & $\begin{array}{l}.02 \\
.00 \\
.04 \\
.01 \\
.00\end{array}$ \\
\hline Probable error.. & \pm 0.04 & \pm 0.04 & - n & - nn- \\
\hline
\end{tabular}

a Mean of two calibrations. 
values determined for the elements of calibration for meter 4 are shown in table 13.

The probable error for the elements of calibration of any $1 / 10-\mathrm{mm}$ subinterval is $\pm 0.04 \mu$. The deviations from the mean of two sets of determinations range from 0.00 to $0.10 \mu$, the average deviation being $0.03 \mu$.

\section{Conclusions}

In making the measurements on the meter bars, the results of which are reported in this paper, every reasonable precaution was taken so that the results would reflect the accuracy and precision that is obtainable with the present NBS equipment.

In the comparison of the bars to determine their total corrections and the corrections to the subintervals, the smallness of the residuals indicates that the standards were in good thermal equilibrium while the observations were being made. Although the observations were made when the temperatures of the bars were very close to $20^{\circ} \mathrm{C}$, the small residuals also indicate that the values used for their respective coefficients of linear expansion are very nearly the true values. In calibrating these meter bars, the effect of any error of $0.01 \mathrm{deg} \mathrm{C}$ in temperature varies from approximately $0.01 \mu / \mathrm{m}$ for the invar bars to $0.10 \mu / \mathrm{m}$ for the stainless steel $(F \mathrm{e}-C \mathrm{r})$ bar.

To a large extent the effect of the imperfections of the lines and surfaces of the bars was compensated for by sufficient repetitions of the observations. It is believed that the final correction to the total length of each of the standards calibrated is not in error by more than $0.2 \mu$, and in most cases is not in error by more than $0.1 \mu$.

There is no evidence that the lengths of the platinum-iridium bars have changed a significant amount during the past 20 years, whereas there is deifnite evidence that the other bars have changed. These changes, however, have become smaller during the ensuing years.

Regarding the possibility of making fewer measurements when intercomparing a group of standards, the 1952 and 1953 series of calibrations showed remarkably good agreement with the final corrections to the bars if a lesser number of direct differences had been considered. This could only be the case if the observed differences in length between the standards are all in excellent agreement. In the calibration of basic standards, a full calibration should be made where all differences between lengths of the bars are directly observed. However, where standards of a lower degree of accuracy are calibrated, a lesser number of direct comparisons would suffice.

As it is known that bars of many materials are unstable in length, the 1952 and 1953 series of comparisons continues the program of maintaining all line standards of length and of obtaining additional knowledge about them, so as to enable the NBS to meet the needs and demands of the present and future for increased accuracy.

The author expresses his appreciation to Lewis V. Judson, Chief, NBS Length Section, for his untiring assistance and guidance and for the many helpful suggestions through the years during which the data reported in this paper were obtained, and to John S. Beers for his assistance with recent observations and computations.

Washington, July 30, 1954. 